SIMULASI PENGUJIAN KARAKTERISTIK POMPA AIR MENGGUNAKAN CATU DAYA MODUL SURYA DAN BATERAI SIKLUS DALAM

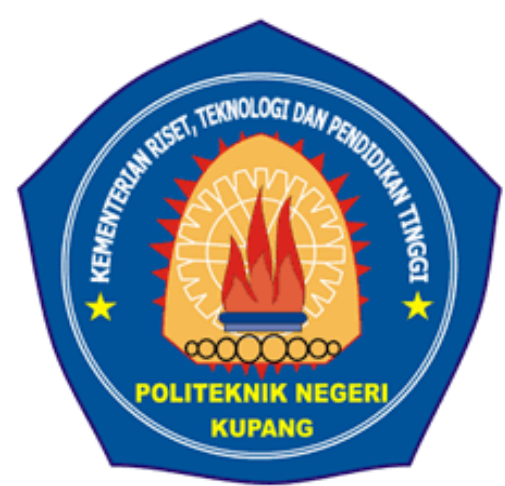

TUGAS AKHIR

Sebagai salah satu syarat untuk memperoleh gelar Ahli Madya (A.Md) pada

Program Studi Teknik Listrik

Oleh

Mevi Febrianto Mata Ratu NIM : 1623734586

PROGRAM STUDI TEKNIK LISTRIK

JURUSAN TEKNIK ELEKTRO

POLITEKNIK NEGERI KUPANG

2019 


\section{LEMBAR PENGESAHAN \\ SIMULASI PENGUJIAN KARAKTERISTIK POMPA AIR \\ MENGGUNAKAN CATU DAYA MODUL SURYA DAN BATERAI \\ SIKLUS DALAM \\ TUGAS AKHIR}

Oleh:

Mevi Febrianto Mata Ratu

1623734586

Pembimbing

3. Dr. Rusman Sinaga, ST., M.Si

NIP. 196510071990031002

4. Mikael Namas, S.Si., M.Si

NIP. 196212111995121001

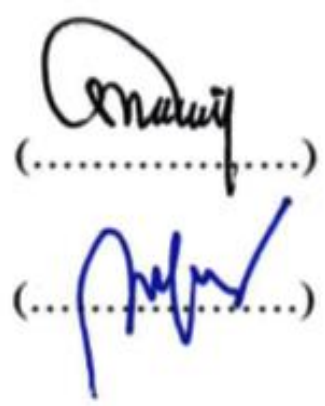

Tim Penguji

1. Ketua tim penguji

: Dr. Julius A. Tanesab, ST., M.Eng

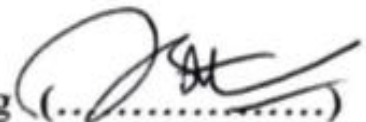
NIP. 197811282002121000

2. Penguji pendamping I : Ir. Arsono Subiantoko, MT NIP. 195806011991031002

3. Penguji pendamping II : Yohanes Suban Peli, SST., M.Si

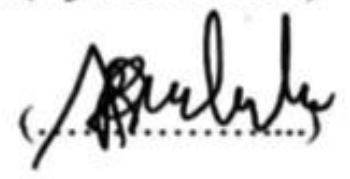
NIP. 196411121991031002

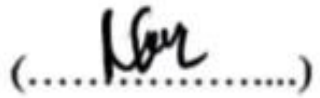

Kupang, 30 September 2019

Mengetahui:

Ketua Jurusan Teknik Elektro PoliteknikNeger/ Kupang

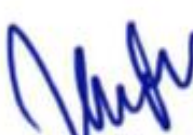

Jemsradd Sine/ST.,M.Eng

NIP.197fp5 92002121002 


\section{KATA PENGANTAR}

Segala Puji dan Syukur penulis panjatkan kepada Tuhan Yang Maha Esa karena atas Berkat dan Rahmat-Nya Tugas Akhir ini dapat diselesaikan. Dalam menyelesaikan Tugas Akhir ini Penulis mendapat bantuan dari berbagai pihak, oleh karena itu pada kesempatan ini penulis mengucapkan terimakasih kepada:

1. Ibu Nonce Farida Tuati, SE. M.Si, selaku Direktur Politeknik Negeri Kupang.

2. Bapak Jemsrado Sine, ST.M.Eng, Selaku Ketua Jurusan Teknik Elektro Politeknik Negeri Kupang.

3. Bapak Dr. Rusman Sinaga, ST., M.Si Selaku Pembimbing I.

4. Bapak Mikhael Namas, S.Si. M.Si Selaku pembimbing II.

5. Kedua orang tua tersayang, serta kakak dan adik yang telah memberikan dukungan kepada Penulis.

6. Teman-teman yang telah banyak membantu dalam penyusunan Tugas Akhir ini.

Penulis menyadari bahwa penulisan Tugas Akhir ini masih jauh dari kesempurnaan, oleh karena itu saran dan kritik yang bersifat membangun sangat diharapkan demi kesempurnaan Tugas Akhir ini.

Semoga Tugas Akhir ini dapat bermanfaat bagi pembaca dan seluruh pihak yang berkepentingan dalam meningkatkan ilmu pengetahuan.

Kupang, 30 Septemmber 2019

Penulis

Mevi Febrianto Mata Ratu 


\section{DAFTAR ISI}

Halaman

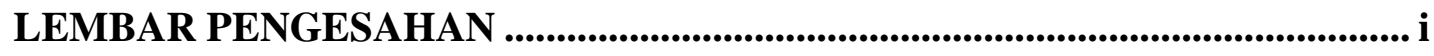

KATA PENGANTAR ........................................................................................ ii

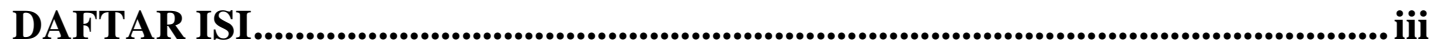

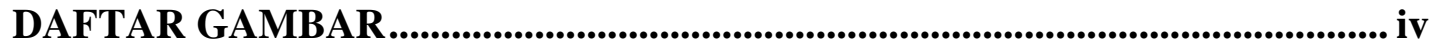

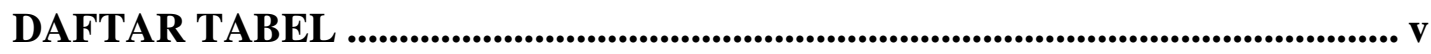

\section{BAB I PENDAHULIAN}

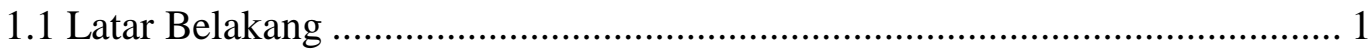

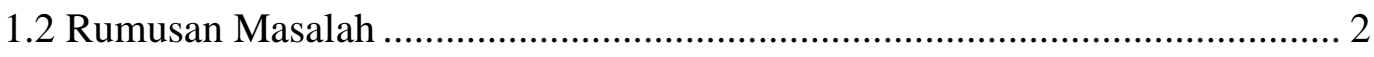

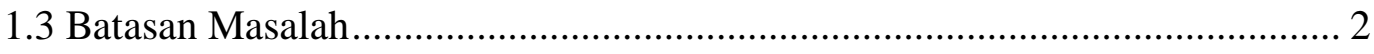

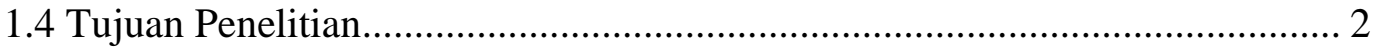

\section{BAB II TINJAUAN PUSTAKA}

2.1 Pompa Air Bertenaga Surya (PABS) ........................................................ 3

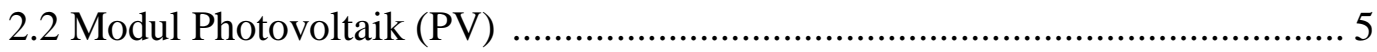

2.3 Solar Charge Controller (SCC) ….................................................... 8

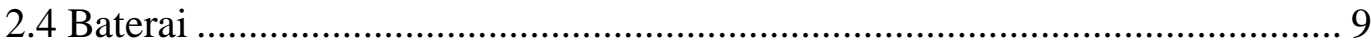

\section{BAB III METODOLOGI PENELITIAN}

3.1 Tempat dan Waktu Penelitian ................................................................. 10

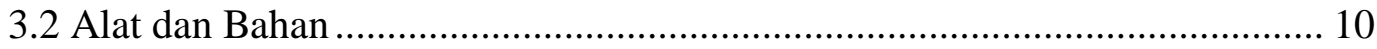

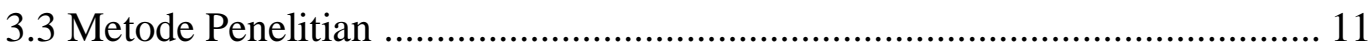

\section{BAB IV PEMBAHASAN}

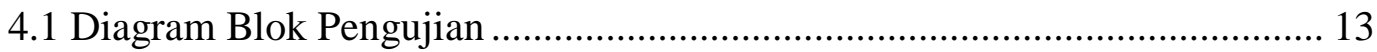

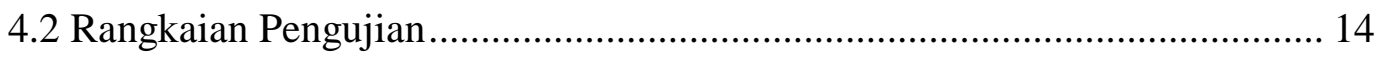

4.3 Komponen Pompa Air Bertenaga Surya .................................................. 16

4.4 Pengujian Modul PV Dan Pompa Air DC ................................................. 19

4.5 Hasil Pengujian Karakteristik Modul Surya 200 WP................................. 20

4.6 Hasil Pengujian Pompa Air DC 50 Watt..................................................... 21

\section{BAB V PENUTUP}

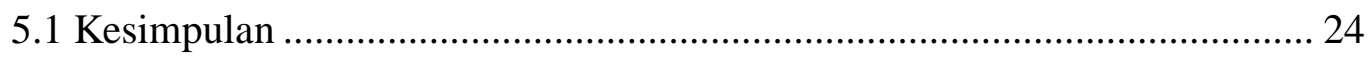

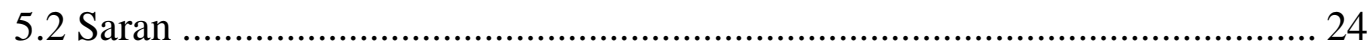

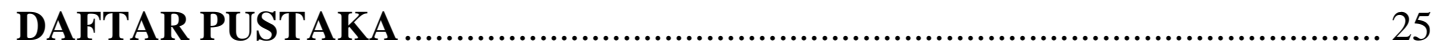




\section{DAFTAR GAMBAR}

\section{Halaman}

Gambar 2.1. Skema Sistem Pompa Air Menggunakan Modul PV ............................. 4

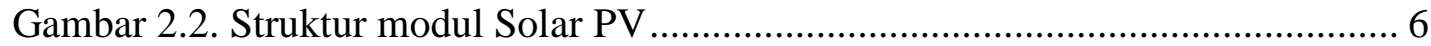

Gambar 2.3. Kurva perubahan tegangan dan arus Solar PV terhadap radiasi matahari ....... 7

Gambar 2.4. Kurva perubahan tegangan dan arus Solar PV terhadap suhu ............... 9

Gambar 2.5. Rangkaian Solar Charge Controller …………….................................. 8

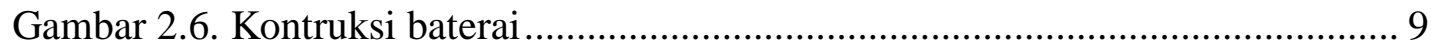

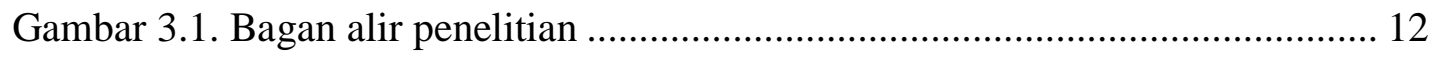

Gambar 4.1. Diagram Blok Pompa Air Menggunakan Modul PV ........................... 13

Gambar 4.2. Rangkaian Pengukuran Arus Hubung Singkat (Isc) ............................ 14

Gambar 4.3. Rangkaian Pengukuran Tegangan Rangkaian Terbuka (Voc) ............. 15

Gambar 4.4. Rangkaian Pengukuran Arus - Tegangan Pompa Air.......................... 15

Gambar 4.5. Model Simulasi Pengujian Pompa Air .................................................. 16

Gambar 4.6. Panel Surya Monocrystalline Type MY200S-24 …………………..... 17

Gambar 4.7. Pompa Air DC 12 Volt, 50 Watt ........................................................ 17

Gambar 4.8. Solar Charge Controller ……………….......................................... 18

Gambar 4.9. Baterai VRLA Deep Cycle Type WPS 6 - CNF - 100 ....................... 19

Gambar 4.10. Kurva Perubahan Arus Dan Tegangan Modul PV 200 WP ............... 21

Gambar 4.11. Karakteristik Debit Air Terhadap Ketinggian Tandon........................ 22

Gambar 4.12. Pengaruh Ketinggian Tandon Terhadap Arus Listrik Pada Pompa ... 23 


\section{DAFTAR TABEL}

\section{Halaman}

Tabel 3.1 Waktu Penelitian Tugas Akhir............................................................... 10

Tabel 4.1 Hasil Pengukuran Modul PV 200 WP .................................................. 20

Tabel 4.2 Hasil Pengujian Pompa Air DC 50 Watt .............................................. 22 


\section{BAB I \\ PENDAHULUAN}

\subsection{Latar Belakang}

Masih terdapat 30.910 dari 78.011 rumah tangga di Kabupaten Kupang yang belum mendapatkan pasokan energi listrik dengan rasio elektrifikasi $60 \%$. Rata-rata rumah tangga yang belum mendapatkan pasokan energi listrik tersebut berada di perdesaan terpencil yang sulit dijangkau oleh jaringan PLN (Sinaga $\mathrm{R}$ et al. 2019). Salah satu sumber penghasilan utama di pedesaan Kabupaten Kupang adalah sektor pertanian. Selain untuk penerangan dimalam hari para petani sangat membutuhkan listrik agar dapat mengoperasikan pompa air listrik untuk mendapatkan air dari sumur karena curah hujan di Kabupaten Kupang relatif kecil sepanjang tahun. Kebutuhan energi listrik terutama untuk pedesaan yang belum mendapatkan pasokan energi listrik PLN salah satunya adalah penggunaan modul photovoltaic (PV), karena disamping Modul PV tidak membutuhkan bahan bakar energi fosil yang sulit didapatkan di pedesaan, penggunaan modul PV juga dapat mengurangi emisi Gas Rumah Kaca (GRK) yang ditimbulkan oleh emisi $\mathrm{CO}_{2}$, dan dengan penggunaan listrik tenaga surya maka dapat mendukung program pemerintah untuk penurunan emisi Gas Rumah Kaca (GRK) dimana target penurunan emisi termuat dalam UndangUndang Nomer 16 Tahun 2016 tentang Persetujuan Paris Atas Konvensi Kerangka Kerja Perserikatan Bangsa-Bangsa Mengenai Perubahan Iklim. Nationally Determined Contribution (NDC) Indonesia adalah penurunan emisi GRK Tahun 2030 sebesar 29\% dengan upaya sendiri dan $41 \%$ jika ada kerja sama internasional (UU RI No.16 Tahun 2016), karena penggunaan Modul PV akan mengurangi proses penyediaan energi listrik melalui pembangkit tenaga listrik berbahan bakar fosil yang menimbulkan emisi $\mathrm{CO}_{2}$.

Penawaran dari produk-produk paket Pompa Air Bertenaga Surya (PABS) untuk konsumen sering tidak sesuai dengan penggunaannya pada kondisi di lapangan terutama pada sistem catu daya yang digunakan dan juga kemampuan pompa untuk mengangkat air dari sumur ke penampungan, karena karakteristik PABS ini belum diketahui secara pasti, sehingga penelitian ini yang diberi 
judul "Simulasi Pengujian Karakteristik Pompa Air Menggunakan Catu Daya Modul Surya dan Baterai Siklus Dalam”, sangat perlu dilakukan.

\subsection{Rumusan Masalah}

Rumusan masalah dari penelitian ini adalah sebagai berikut:

- Bagaimana Karakteristik Modul PV 200 Wp.

- Berapa besar efisiensi modul PV $200 \mathrm{Wp}$ yang digunakan.

- Bagaimana Karakteristik Pompa Air DC 50 Watt menggunakan catu daya modul PV 200 Wp dan Baterai Siklus Dalam (Deep Cycle)

\subsection{Batasan Masalah}

Penelitian ini menggunaan Modul PV 200 Wp monocrystalline dan baterai siklus dalam (Deep Cycle) VRLA (Valve Regulated Lead Acid) 100 Ah dengan pompa air DC 12V 50 W. Pengujian skala laboratorium yang dilakukan di Lab General, model simulasi menggunakan bak plastik sebagai penampungan air yang diasumsikan sebagai sumur dan menggunakan pipa PVC untuk memompakan air untuk simulasi berbagai ketinggian.

\subsection{Tujuan Penelitian}

Tujuan umum penelitian ini adalah untuk mengetahui karakteristik PABS khususnya menggunakan pompa air DC 12V, 50W dengan catu daya mengunakan Modul PV 200 Wp yang dilengkapi dengan baterai VRLA (Valve Regulated Lead Acid) 100 Ah. Untuk mencapai tujuan tersebut maka tujuan khusus penelitian ini antara lain adalah:

- Mengetahui Karakteristik Modul PV 200 Wp

- Mengetahui efisiensi modul PV $200 \mathrm{Wp}$

- Mengetahui Karakteristik Pompa Air 


\section{BAB II \\ TINJAUAN PUSTAKA}

\subsection{Pompa Air Bertenaga Surya (PABS)}

Pompa Air Bertenaga Surya (PABS) membutuhkan energi matahari sebagai energi primer untuk dikonversikan menjadi energi listrik melalui modul PV. Hasil penelitian membuktikan bahwa di Kabupaten Kupang Intensitas sinar matahari sangat optimum pada musim kemarau. Pada pagi, siang dan sore hari radiasi sinar matahari sangat berpengaruh terhadap keluaran energi panel surya (Sinaga R, 2011). Perubahan intensitas sinar matahari dan sudut datang sinar matahari sangat berpengaruh terhadap tegangan yang diterima panel surya. Intensitas radiasi sinar matahari rata-rata di Nusa Tenggara Timur sebesar $5.117 \mathrm{Wh} / \mathrm{m}^{2} / \mathrm{hari}$, yang berpotensi untuk membangkitkan energi listrik (Rahardjo I dan Fitriana I, 2014).

Kinerja panel surya berupa output daya maksimum bervariasi dengan musim. Pada akhir musim panas atau kemarau, kinerja panel surya cenderung meningkat. Berdasarkan tinjauan kriteria efisien biaya, efektifitas dan ramah lingkungan dalam mengurangi emisi $\mathrm{CO}_{2}$, pilihan terbaik penyediaan energi listrik skala kecil adalah menggunakan panel surya dan dengan catu daya menggunakan panel surya mampu menggerakkan pompa air. (Sinaga R. Dkk, 2017)

Pompa Air Bertenaga Surya (PABS) mampu beroperasi selama 24 jam sehari. Pada pagi hingga sore hari pompa air menggunakan energi listrik yang dihasilkan oleh panel surya, sekaligus panel surya mengisi baterai. Pada malam hari pompa menggunakan energi listrik dari baterai (Taufik M, 2016). Sistem PABS merupakan teknologi yang paling cocok untuk irigasi pertanian. Kinerja PABS dengan kapasitas yang sama dengan pompa air yang digerakkan secara konvensional memiliki efisiensi yang jauh lebih tinggi. Laju aliran maksimum yang diperoleh PABS adalah 69 liter/menit sedangkan pompa air konvensional adalah 65 liter/menit. Untuk memilih pompa air adalah dengan menentukan debit air aliran pompa, total head dan jumlah kerugian tekanan akibat panjang pipa dan fitting. Formulasi untuk menentukan kapasitas daya pompa air disajikan pada persamaan (1) (Tukiman, 2013): 


$$
\mathrm{P}=\frac{Q \cdot H \cdot B j f}{F k \cdot \eta}
$$

Dimana:

$\mathrm{P} \quad$ : Daya pompa air (Watt)

Q : Debit air $\left(\mathrm{m}^{3} / \mathrm{jam}\right)$

$\mathrm{H}$ : Total head (Sesuai katalog pompa air)

$\eta \quad$ : Efisiensi (\%)

Bjf : Berat jenis fluida $\left(\mathrm{Kg} / \mathrm{m}^{3}\right)$

$\mathrm{Fk}$ : Faktor konversi satuan daya

Penyediaan sistem PABS dirancang dan diinstalasi sesuai dengan lokasi sumur sebagai sumber air yang dibutuhkan dengan menggunakan bahan panel surya yang dilengkapi dengan tiang penyangga, pompa air, baterai, Solar Charge Controller (SCC) yang dilengkapi dengan kotak panel (panel box) dan tandon air yang ditopang oleh tower. PABS yang dirancang aman terhadap sengatan listrik karena menggunakan catu daya DC yang dapat beroperasi selama 24 jam sehari dengan debit air 70 liter per menit. Skema sistem pompa air bertenaga surya disajikan pada Gambar 2.1.

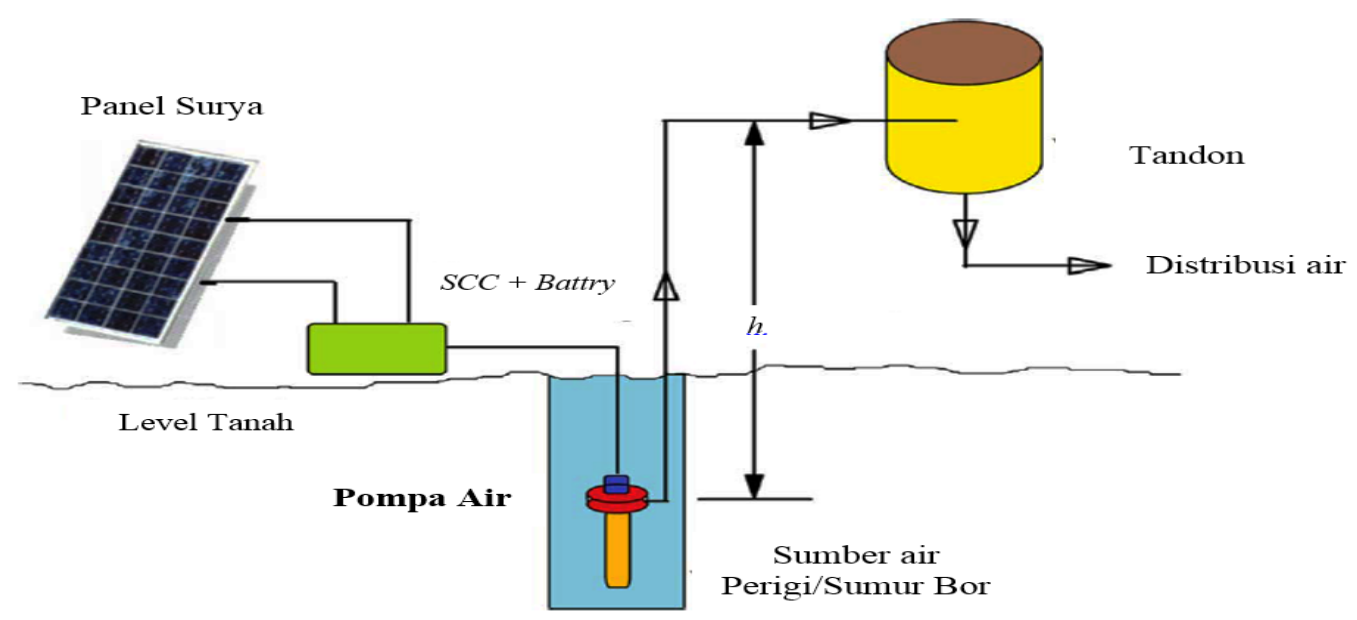

Gambar 2.1 Skema sistem Pompa Air Bertenaga Surya (PABS)

Karakteristik dari pompa merupakan hubungan antara tekanan yang dibangkitkan (head) dan kecepatan aliran volume (kapasitas). Karakteristik dapat juga menyertakan Kurva efisiensi dan harga brake horse power. Karakteristik pompa dapat digambarkan dalam kurva karakteristik yang 
melukiskan jalannya lintasan dan besaran - besaran kapasitas, besaran besaran tersebut adalah:

- Head pompa $(\mathrm{H})$

- Daya pompa $(\mathrm{P})$

- Efisiensi pompa (П)

\subsection{Modul Photovoltaic (PV)}

Modul Photovoltaic (PV) merupakan suatu alat yang dapat mengubah energi surya menjadi energi listrik. Sel fotovoltaik merupakan komponen utama dari modul fotovoltaik. Sel ini terbuat dari bahan semikonduktor yang menangkap sinar matahari dan mengubahnya menjadi listrik. Sel-sel saling terhubung secara seri untuk mendapatkan tegangan total yang lebih tinggi melalui kawat busbar. Bahan yang digunakan untuk sel PV umumnya adalah silikon, seperti polycrystalline dan monocrystalline (Ramadhani, 2012).

Pada dasarnya sel fotovoltaik merupakan suatu dioda semikonduktor yang bekerja menurut suatu proses khusus yang dinamakan proses tidak seimbang (non-equilibrium pocess) dan berlandaskan efek fotovoltaik (photovoltaic effect). Sel fotovoltaik merupakan suatu P-N junction dari silikon kristal tunggal. Dengan menggunakan photo-electric effect dari bahan semikonduktor sehingga dapat mengumpulkan radiasi matahari dan mengkonversinya menjadi energi listrik. Energi listrik hasil dari Solar PV tersebut berupa arus DC dan bisa langsung digunakan atau bisa juga menggunakan baterai sebagai sistem penyimpan sehingga dapat digunakan pada saat dibutuhkan terutama pada malam hari. Struktur Solar PV disajikan pada Gambar 2.2. 


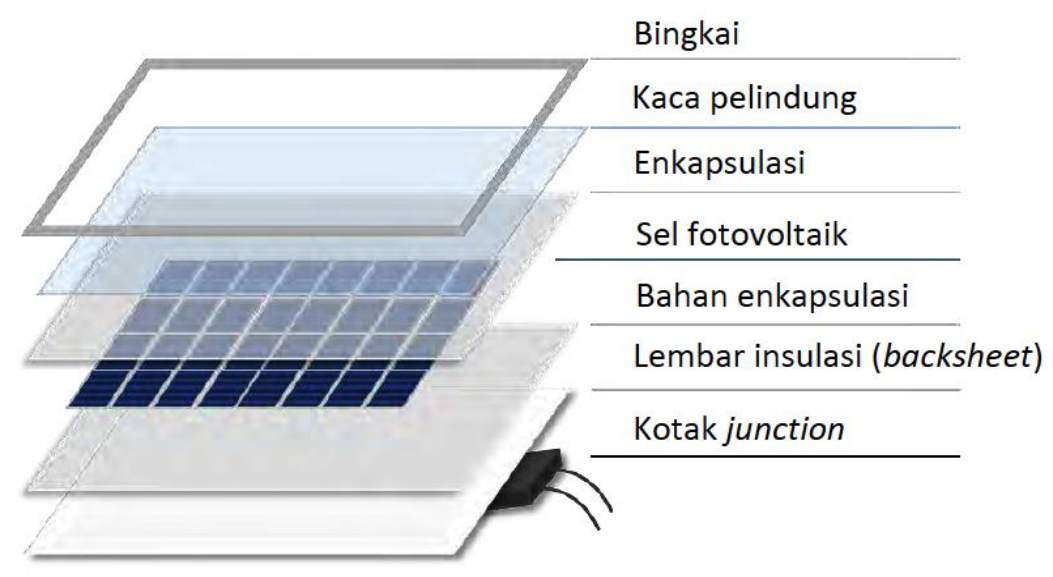

Gambar 2.2. Struktur modul Solar PV

Sumber: (Ramadhani, 2012)

Karakteristik penting Solar PV terdiri dari tegangan open circuit (Voc), arus hubung singkat (Isc), efek perubahan radiasi matahari, efek perubahan temperatur serta karakteristik tegangan-arus pada Solar PV. Tegangan open circuit (Voc) adalah tegangan yang dibaca pada saat arus tidak mengalir atau bisa disebut juga arus sama dengan nol. Cara untuk mencapai open circuit (Voc) yaitu dengan menghubungkan kutub positif dan kutub negatif modul surya dengan voltmeter, sehingga akan terlihat nilai tegangan open circuit Solar PV pada voltmeter.

Arus hubung singkat (Isc) adalah arus maksimal yang dihasilkan oleh Solar PV dengan cara menghubung singkatkan kutub positif dengan kutub negatif pada solar PV. Nilai Isc akan terbaca pada amperemeter. Arus yang dihasilkan Solar PV dapat menentukan seberapa cepat modul tersebut mengisi sebuah baterai. Selain itu, arus listrik yang mengalir pada Solar PV juga menentukan daya maksimum Solar PV yang digunakan. Efek perubahan negatif radiasi matahari terjadi apabila jumlah energi surya yang diterima Solar PV berkurang atau intensitas cahayanya melemah, maka besar tegangan dan arus listrik yang dihasilkan juga akan menurun. Penurunan tegangan relatif lebih kecil dibandingkan penurunan arus listriknya seperti yang disajikan pada Gambar 2.3. 


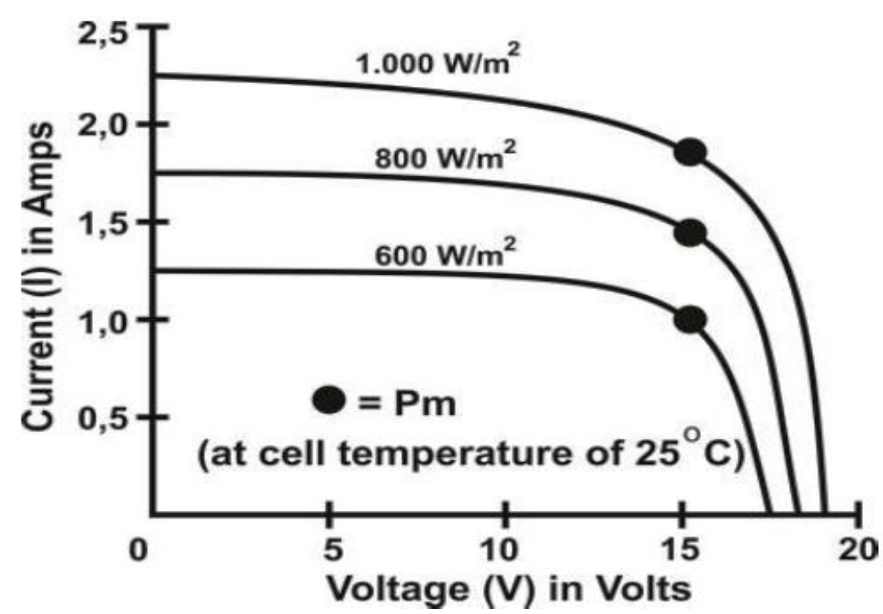

Gambar 2.3. Kurva perubahan tegangan dan arus Solar PV terhadap radiasi matahari

Sumber: (Satwiko S, 2012).

Solar PV dapat bekerja secara optimal pada suhu konstan yaitu $25^{\circ} \mathrm{C}$ atau sesuai degan name plate yang tertulis pada modul tersebut. Jika suhu disekitar Solar PV meningkat melebihi $25^{\circ} \mathrm{C}$, maka akan mempengaruhi fill factor sehingga tegangan akan berkurang. Sedangkan sebaliknya, arus yang dihasilkan akan meningkat seiring dengan meningkatnya suhu pada Solar PV. Kurva perubahan arus dan tegangan berdasarkan perubahan suhu disajikan pada Gambar 2.4

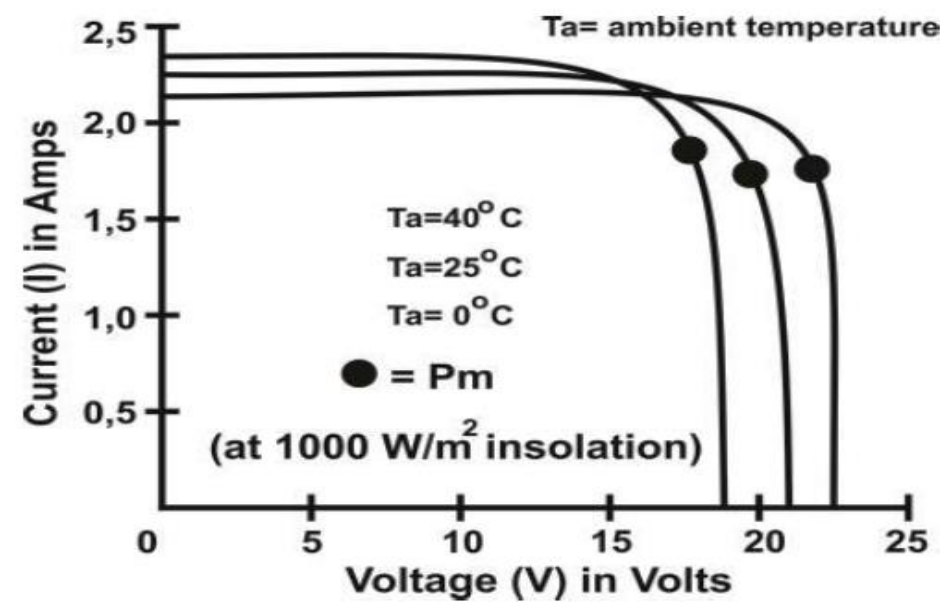

Gambar 2.4. Kurva perubahan tegangan dan arus Solar PV terhadap suhu Sumber: (Satwiko S, 2012). 


\subsection{Solar Charge Controller (SCC)}

Proses pengisian arus listrik dengan Solar PV ke baterai tidak sama dengan pengisi baterai konvensional (battery charger) yang menggunakan listrik. Hal ini disebabkan karena arus listrik yang dihasilkan Solar PV bisa besar, bisa juga kecil tergantung dari radiasi matahari. Proses pengisian akan berlangsung selama ada radiasi matahari, tidak melihat apakah baterai tersebut sudah penuh atau belum. Solar charge controller (SCC) atau juga dikenal sebagai Battery Charge Regulator (BCR) adalah komponen elektronika daya pada sistem PABS untuk mengatur pengisian baterai dari tangkapan sinar matahari melalui modul PV. Perangkat ini beroperasi dengan cara mengatur tegangan dan arus pengisian berdasarkan daya yang tersedia dari larik modul PV dan status pengisian baterai (state of charge/SoC). Rangkaian Solar Charge Controller dapat dilihat pada Gambar 2.5.

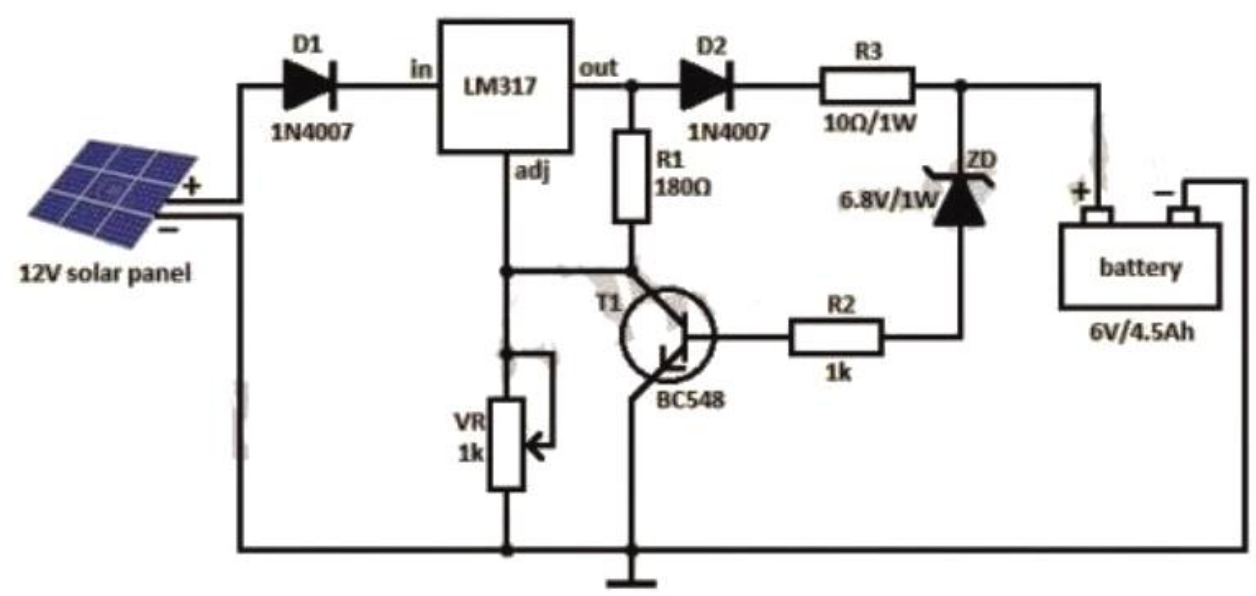

Gambar 2.5 Rangkaian Solar Charge Controller Sumber: (Pribadi AB, 2016) 


\subsection{Baterai}

Baterai adalah alat penyimpanan tenaga listrik arus searah (DC). Secara garis besar, baterai dibedakan berdasarkan aplikasi dan kontruksinya. Berdasarkan aplikasi maka baterai dibedakan untuk automotif, marine dan deep cylcle. Deep cycle itu meliputi baterai yang biasa digunakan untuk photovoltaic dan back up power. Sedangkan secara kontruksi maka baterai dibedakan menjadi tipe basah, gel dan AGM (Absorbed Glass Mat). Baterai jenis AGM biasanya juga dikenal dengan VRLA (valve regulated lead acid).

Baterai kering deep cycle juga dirancang untuk menghasilkan tegangan yang stabil dan konsisten. Penurunan kemampuannya tidak lebih dari $1-2 \%$ per bulan tanpa perlu di - charger. Bandingkan dengan baterai konvensional yang bisa mencapai $2 \%$ per minggu untuk self discharger. Konsekuensinya untuk charging pengisian arus ke dalam baterai kering harus lebih kecil dibandingkan baterai konvensional sehingga butuh waktu yang lebih lama untuk pengisian muatannnya. Antara tipe gel dan AGM hampir mirip hanya saja baterai AGM mempunyai semua kelebihan yang dimiliki tipe gel tanpa memiliki kekurangannya. Kekurangan tipe gel adalah pada waktu discharger maka tegangannya harus $20 \%$ lebih rendah dari baterai tipe AGM ataupun basah. Bila overcharge maka akan timbul rongga di dalam gelnya yang sulit diperbaiki sehingga berkurang kapasitas muatannya. Kontruksi pada baterai dapat dilihat pada Gambar 2.6.

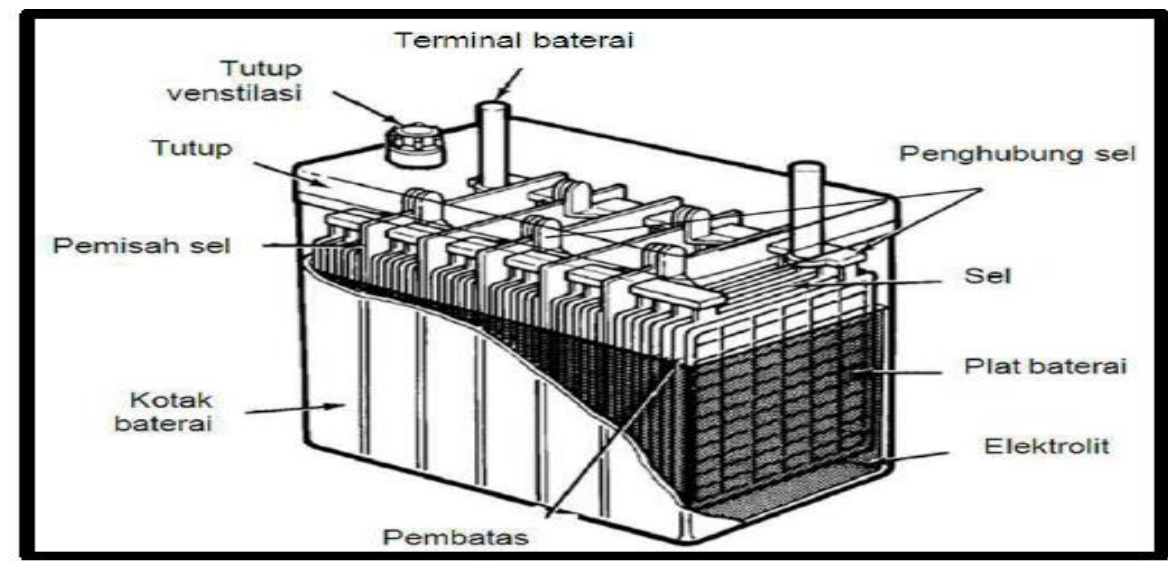

Gambar 2.6 Kontruksi baterai

Sumber: (Pribadi AB, 2016) 


\section{BAB III \\ METODOLOGI PENELITIAN}

\subsection{Tempat dan Waktu Penelitian}

Penelitian ini dilaksanakan di Laboratorium General Politeknik Negeri Kupang, sedangkan waktu yang dibutuhkan dalam penelitian ini adalah enam bulan (satu semester) mulai bulan April sampai dengan September 2019 terdiri dari persiapan, penyusunan proposal, seminar proposal sampai dengan Ujian Tugas Akhir. Waktu penelitian Tugas Akhir disajikan pada Tabel 3.1.

Tabel 3.1 Waktu penelitian Tugas Akhir

\begin{tabular}{|c|c|c|c|c|c|c|c|c|c|c|c|c|c|c|c|c|c|c|c|c|}
\hline \multirow{3}{*}{ No } & \multirow{3}{*}{ Uraian Kegiatan } & \multicolumn{19}{|c|}{ Waktu Pelaksanaan } \\
\hline & & & \multicolumn{2}{|c|}{ April } & \multicolumn{3}{|c|}{ Mei } & \multicolumn{3}{|c|}{ Juni } & & \multicolumn{3}{|c|}{ Juli } & \multicolumn{3}{|c|}{ Agustus } & \multicolumn{3}{|c|}{ September } \\
\hline & & & $2 \mid 3$ & 4 & 1 & 2 & 14 & 1 & 2 & 3 & $t$ & 2 & & 4 & 12 & & 4 & & & 4 \\
\hline 1 & Persiapan & & & & & & & & & & & & & & & & & & & \\
\hline 2 & Penyusunan Proposal & & & & & & & & & & & & & & & & & & & \\
\hline 3 & Konsultasi Proposal & & & & & & & & & & & & & & & & & & & \\
\hline 4 & Seminar Proposal & & & & & & & & & & & & & & & & & & & \\
\hline 5 & Revisi Proposal & & & & & & & & & & & & & & & & & & & \\
\hline 6 & Pengambian data dan tabulasi & & & & & & & & & & & & & & & & & & & \\
\hline 7 & Penyunsunan T.A & & & & & & & & & & & & & & & & & & & \\
\hline 8 & Konsultasi T.A & & & & & & & & & & & & & & & & & & & \\
\hline 9 & Ujian T.A & & & & & & & & & & & & & & & & & & & \\
\hline 10 & Revisi dan penjilidan T.A. & & & & & & & & & & & & & & & & & & & \\
\hline
\end{tabular}

\subsection{Alat dan Bahan}

Alat yang digunakan dalam penelitian ini antara lain adalah: 1) Solar power meter untuk mengukur radiasi matahari. 2) Thermometer digital untuk mengukur suhu dibawah modul PV. 3) Ampere meter digunakan untuk mengukur arus hubung singkat. 4) Volt meter digital digunakan untuk mengukur tegangan rangkaian terbuka. 5) Clinometer digunakan untuk mengukur derajat kemiringan modul PV sebesar $10^{\circ}$ menghadap utara 6) Kompas digunakan untuk mengukur penempatan posisi modul PV menghadap 
utara dan Stopwatch digunakan untuk mengukur waktu kinerja pompa air yang di indikasikan sebagai pengosongan baterai.

Bahan utama yang digunakan dalam penelitian ini adalah satu unit modul PV 200 Wp. Baterai VRLA (Valve Regulated Lead Acid) 12 Volt 100 Ah, Solar Charge Controler (SCC), Pompa air DC 12V, 50 Watt dan Kabel penghubung.

\subsection{Metode Penelitian}

Metode yang digunakan untuk memperoleh data sekunder adalah menggunakan metode studi literatur, sedangkan untuk mendapatkan data primer menggunakan metode observasi yaitu melakukan pengukuran variabel radiasi matahari (SR), suhu modul $(\mathrm{S})$, arus hubung singkat $\left(\mathrm{I}_{\mathrm{SC}}\right)$, tegangan rangkaian terbuka $\left(\mathrm{V}_{\mathrm{OC}}\right)$, Debit air $\left(\mathrm{m}^{3}\right)$ dengan simulasi variasi ketinggian (h) tendon dan waktu pengosongan baterai melalui pembebanan pompa air.

Metode analisis data yang menggunakan metode kuantitatif yaitu melakukan kuantifikasi untuk memperoleh keluaran daya modul PV yang merupakan arus hubung singkat $\left(\mathrm{I}_{\mathrm{sc}}\right)$ berbanding lurus dengan tegangan rangkaian terbuka $\left(\mathrm{V}_{\mathrm{oc}}\right.$ ) pada modul PV dihitung menggunakan persamaan (2) (Napitupuludkk, 2017):

$$
\mathrm{P}_{\mathrm{o}}=\mathrm{I}_{\mathrm{sc}} \cdot \mathrm{V}_{\mathrm{o}}
$$

\section{Dimana:}

$\mathrm{P}_{\mathrm{o}} \quad$ : Daya output Solar PV (W)

$\mathrm{I}_{\mathrm{sc}} \quad$ : Arus hubung singkat (A)

$\mathrm{V}_{\mathrm{oc}}$ : Tegangan rangkaian terbuka $(\mathrm{V})$

Besaran daya radiasi matahari yang datang sebagai daya input modul PV dapat dilakukan dengan perhitungan menggunakan persamaan (3).

$\mathrm{P}_{\mathrm{i}}=\mathrm{SR} . \mathrm{A}_{\mathrm{SPV}}$

Dimana:

$\mathrm{P}_{\mathrm{i}} \quad$ : Daya masuk ke panel surya $(\mathrm{W})$

ASPV : Luas permukaan Solar PV $\left(\mathrm{m}^{2}\right)$

SR : Radiasi matahari $\left(\mathrm{W} / \mathrm{m}^{2}\right)$ 
Effisiensi Solar PV (П) dihitung dengan menggunakan persamaan (4)

$\eta=\frac{\mathrm{Po}}{\mathrm{Pi}} \times 100 \%$

Metode analisis data juga menggunakan metode deskriptif kualitatif yaitu mendeskripsikan pengosongan baterai melalui pembebanan pompa air dan mendeskripsikan volume air yang dapat dipompa berdasarkan simulasi ketinggian tandon. Bagan alir penelitian disajikan pada Gambar 5.1.

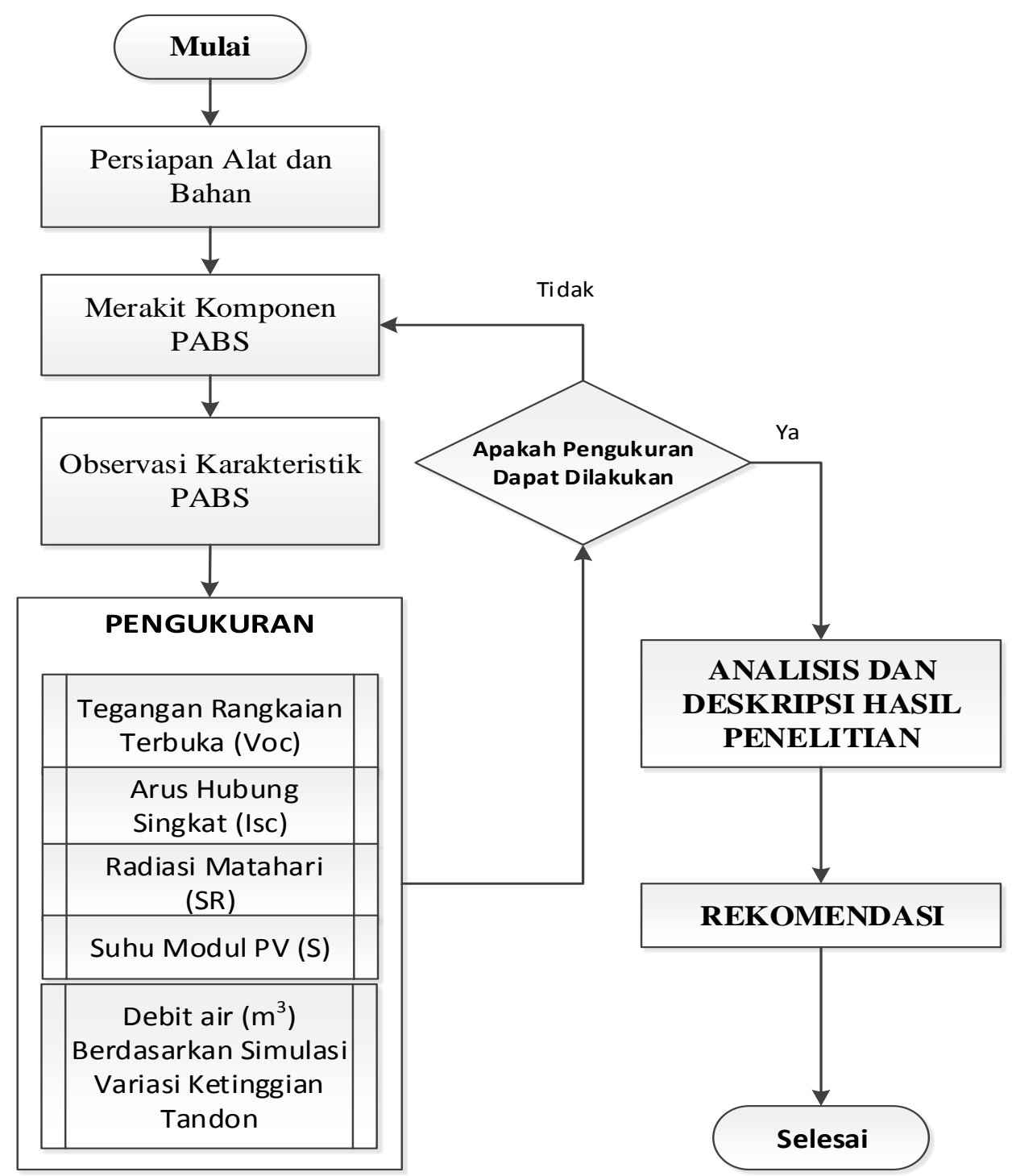

Gambar 3.1. Bagan alir penelitian 


\section{BAB IV \\ HASIL DAN PEMBAHASAN}

\subsection{Diagram Blok Pengujian}

Pengujian pompa air menggunakan modul PV $200 \mathrm{Wp}$ untuk mengetahui karakteristik pompa air dan modul PV 200 Wp. Diagram Blok Pengujian disajikan pada Gambar 4.1.

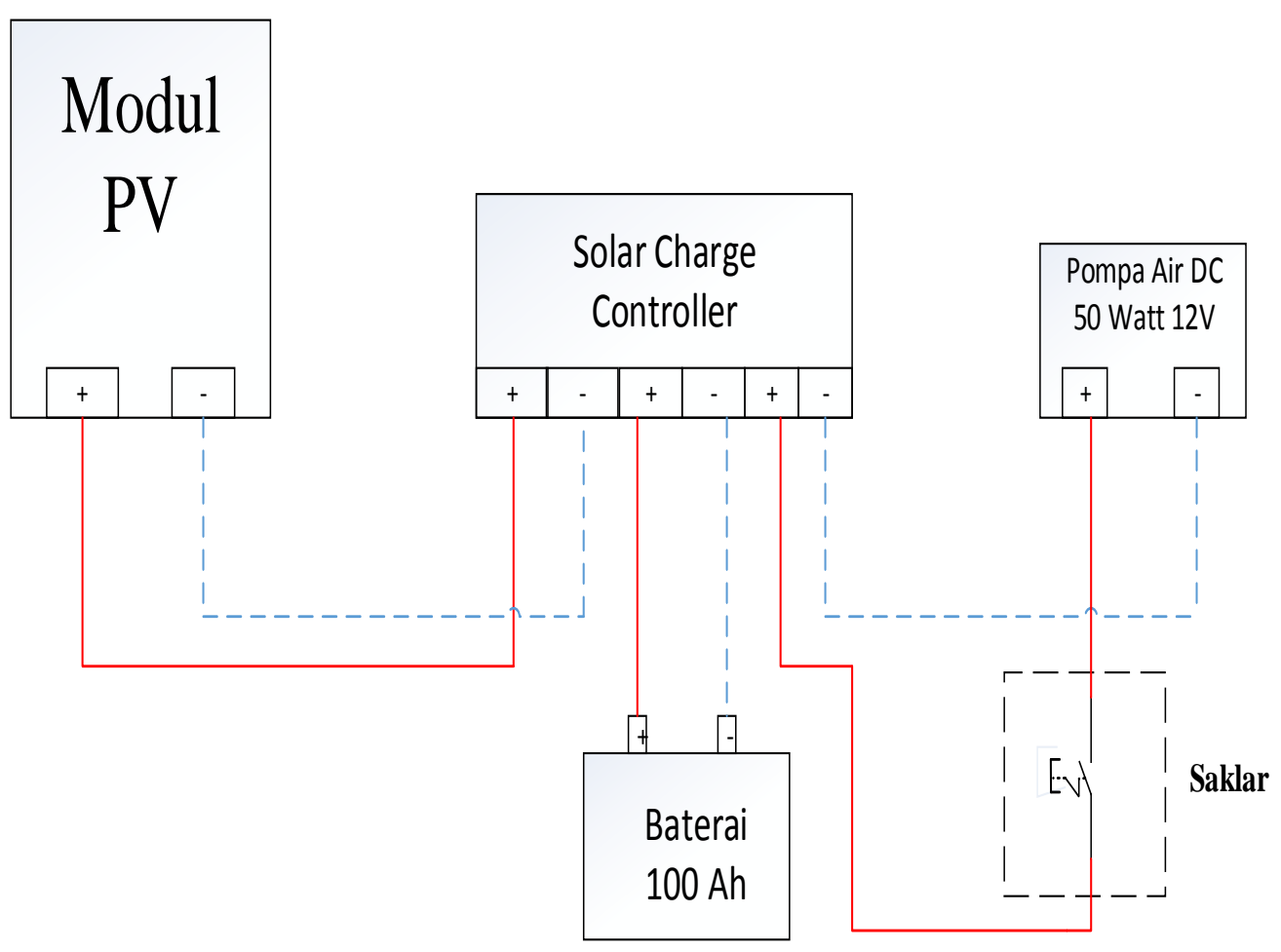

Gambar 4.1 Diagram Blok pompa air bertenaga surya

Pengujian karakteristik modul surya dilakukan berdasarkan pengoperasian kondisi nyata (Real Operation Condition) Test dengan cara pengukuran variable radiasi matahari (SR), suhu (S), arus hubung singkat (Isc), tegangan rangkaian terbuka (Voc) dari modul surya tersebut. Sedangkan untuk pengujian karakteristik pompa air dilakukan dengan cara pengukuran debit air $\left(\mathrm{m}^{3}\right)$ berdasarkan simulasi variasi ketinggian $(\mathrm{h})$ tandon. 
Berdasarkan diagram Blok Gambar 4.1. pengukuran karakteristik modul PV dilakukan saat permukaan modul PV terkena cahaya matahari sehingga akan menampilkan hasil ukur pada alat ukur yang telah dihubungkan ke modul PV secara pararel untuk pengukuran Isc dan Voc. Untuk pengukuran radiasi matahari dengan cara solar power meter diletakan dibawah sinar matahari agar hasil ukur radiasi matahari dapat terbaca pada alat ukur, sedangkan untuk pengukuran suhu dengan cara thermometer laser di tembakan ke bawah modul PV agar mendapatkan hasil pengukuran suhu dibawah modul PV.

Untuk pengujian pompa air dilakukan dengan memvariasikan ketinggian tandon untuk mengetahui lama waktu yang dibutuhkan untuk pengisian tandon pada berbagai ketinggian dan melakukan pengukuran arus - tegangan pompa air.

\subsection{Rangkaian Pengujian}

a. Rangkaian pengukuran Isc dan Voc

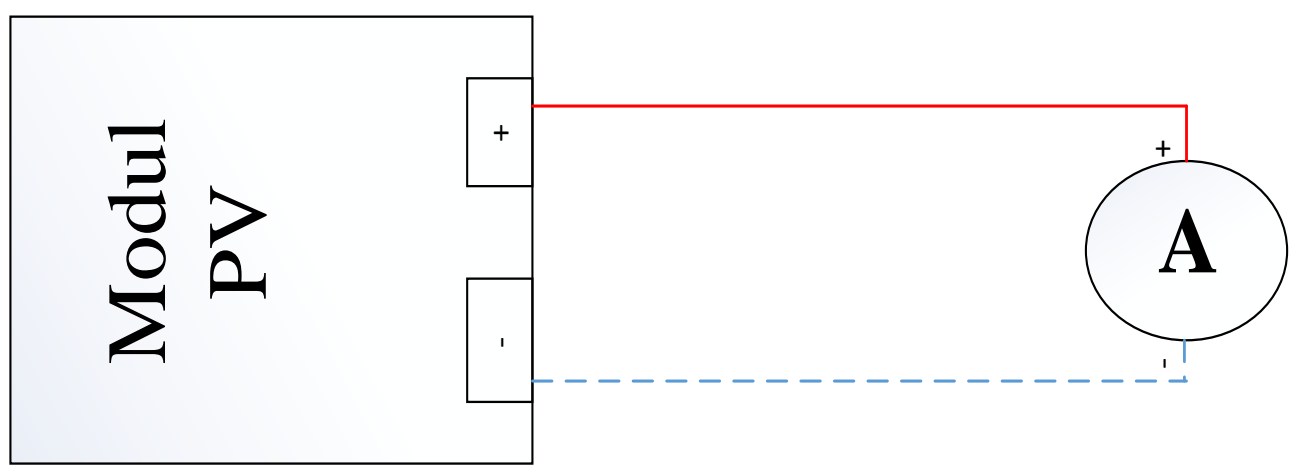

Gambar 4.2 Rangkaian pengukuran arus hubung singkat (Isc) 


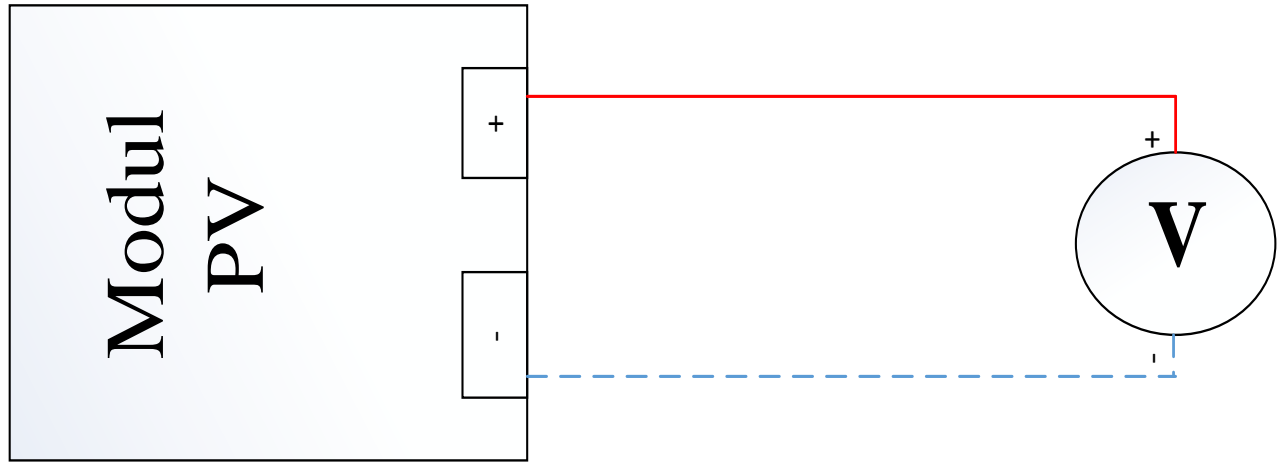

Gambar 4.3 Rangkaian pengukuran tegangan rangkaian terbuka (Voc)

b. Rangkaian pengukuran Ip dan Vp

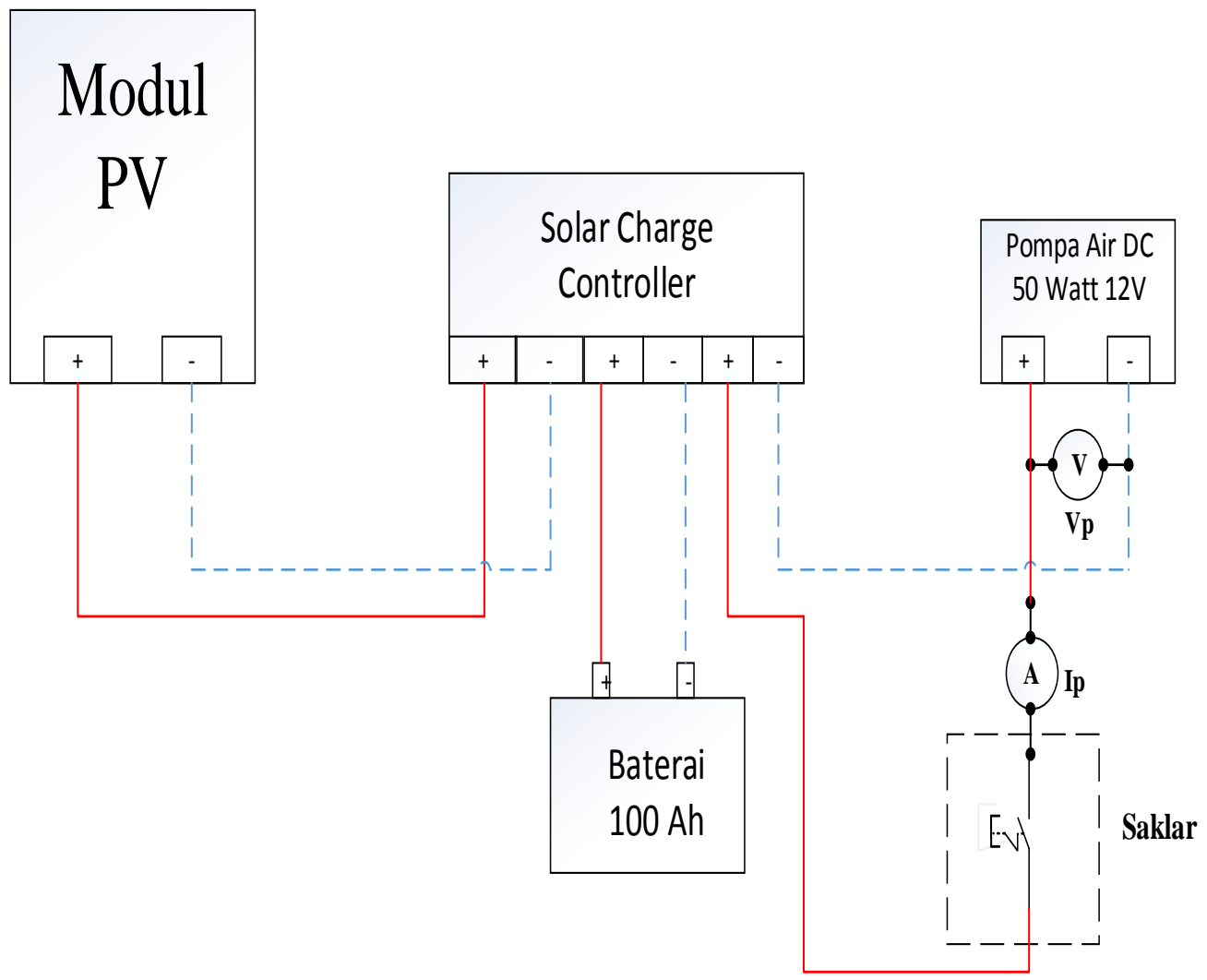

Gambar 4.4 Rangkaian pengukuran arus - tegangan pompa air 
c. Simulasi pengujian pompa air

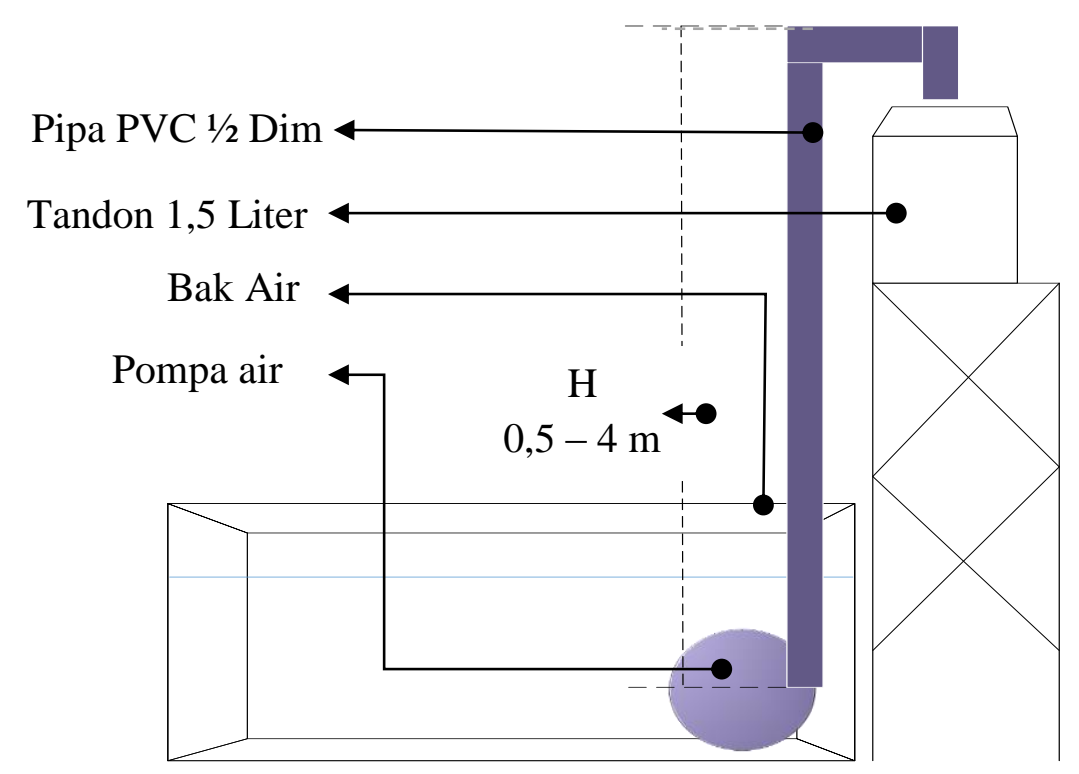

Gambar 4.5 Model simulasi pengujian pompa air

\subsection{Komponen Pompa Air Bertenaga Surya}

A. Modul Surya

Modul surya yang dipakai adalah monocrystalline type MY200S-24 dengan spesifikasi sebagai berikut:

$\begin{array}{ll}\text { Pmax (W) } & : 200 \mathrm{~W} \\ \text { Vmp (A) } & : 37,8 \mathrm{~V} \\ \text { Imp (V) } & : 5,31 \mathrm{~A} \\ \text { Voc (V) } & : 44,8 \mathrm{~V} \\ \text { Isc (A) } & : 5,75 \mathrm{~A} \\ \text { Max System Voltage }(\mathrm{V}) & : 700 \mathrm{~V} \\ \text { Temperature Range }\left({ }^{\circ} \mathrm{C}\right) & :-45{ }^{\circ} \mathrm{C} \sim+80{ }^{\circ} \mathrm{C} \\ \text { Dimension }(\mathrm{mm}) & : 1350 * 1000 * 40 \mathrm{~mm} \\ \text { Intensitas Radiasi }\left(\mathrm{W} / \mathrm{m}^{2}\right) & : 1000 \mathrm{~W} / \mathrm{m}^{2}\end{array}$




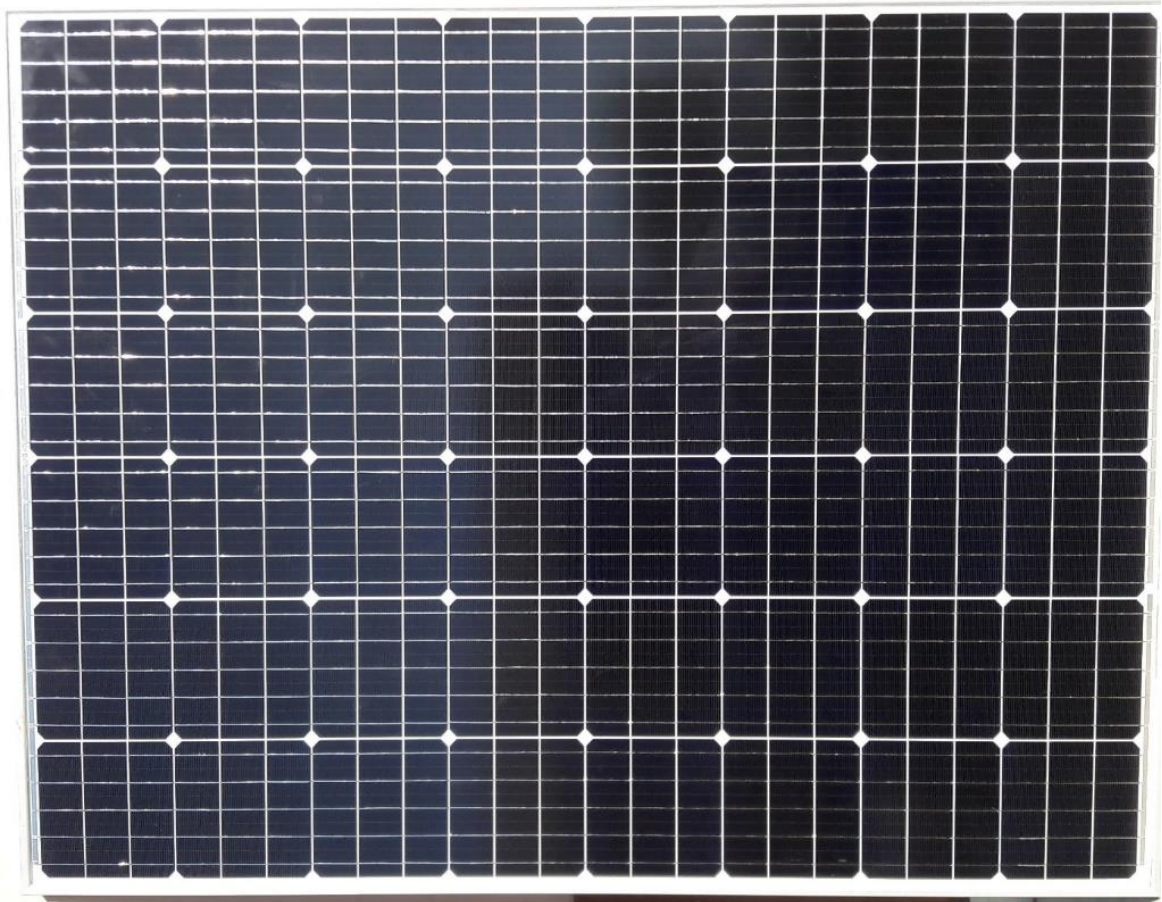

Gambar 4.6 Panel surya monocrystalline type MY200S-24

\section{B. Pompa Air}

Pompa air yang digunakan adalah pompa air DC type celup dengan spesifikasi sebagai berikut:
Tegangan
: DC $12 \mathrm{~V}$
Ketinggian
: 5 meter
Daya pompa
: $50 \mathrm{~W}$
Suhu air max
$: 0-60^{\circ} \mathrm{C}$
Diameter pipa
: $1 / 2 \operatorname{Dim}$
Kecepatan putaran : $5800 \mathrm{rpm}$ 


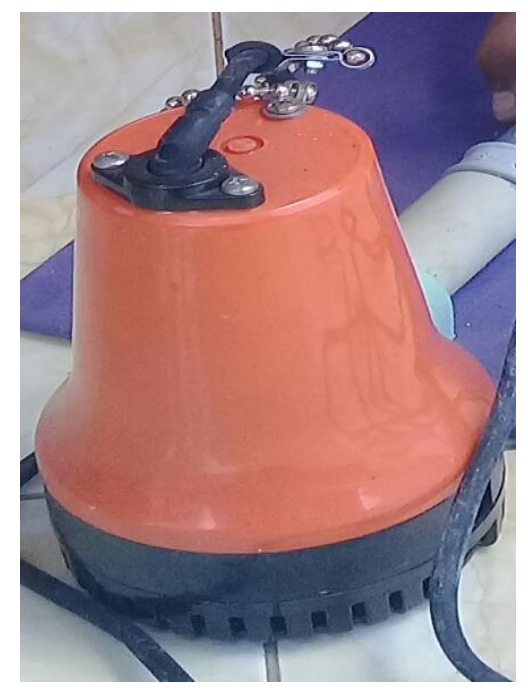

Gambar 4.7 Pompa air DC 12 Volt, 50 Watt

\section{Solar Charge Controller}

Solar charge controller adalah peralatan yang berfungsi untuk mengatur proses pengisian baterai. Hal penting yang perlu diperatikan untuk penggunaan solar charge controller adalah tegangan output ke sistem. Solar charge controller tegangan outputnya biasanya 12, 34, atau 48 Volt, untuk penggunaan pada pompa air DC type celup tegangan yang digunakan adalah 12 volt bermerek PWM dengan spesifikasi sebagai berikut :

Tipe : PWM

Tegangan $: 12 / 24 \mathrm{~V}$

Arus Charging / beban : $10 \mathrm{~A}$

Volt Charging $: 13,7 / 27,4 \mathrm{~V}$

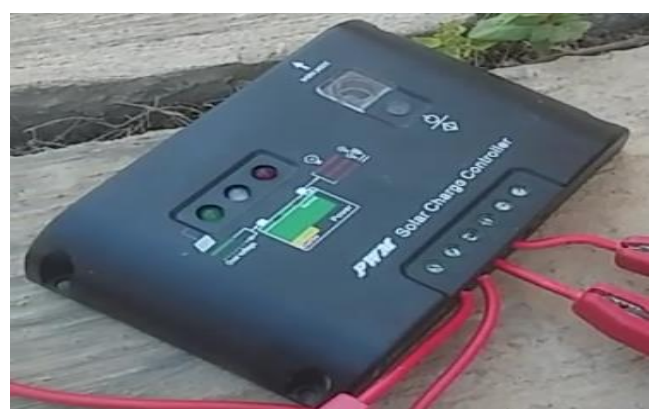

Gambar 4.8 Solar Charge Controller (SCC) 
D. Baterai (Accumulator)

Baterai yang digunakan adalah baterai VRLA deep cycle type WPS 6 - CNF - 100 dengan spesifikasi sebagai berikut:

$\begin{array}{ll}\text { Tegangan } & : 12 \mathrm{~V} \\ \text { Kapasitas } & : 100 \mathrm{Ah} \\ \text { Waktu Max. Pemakaian } & : 10 \mathrm{hr}\end{array}$

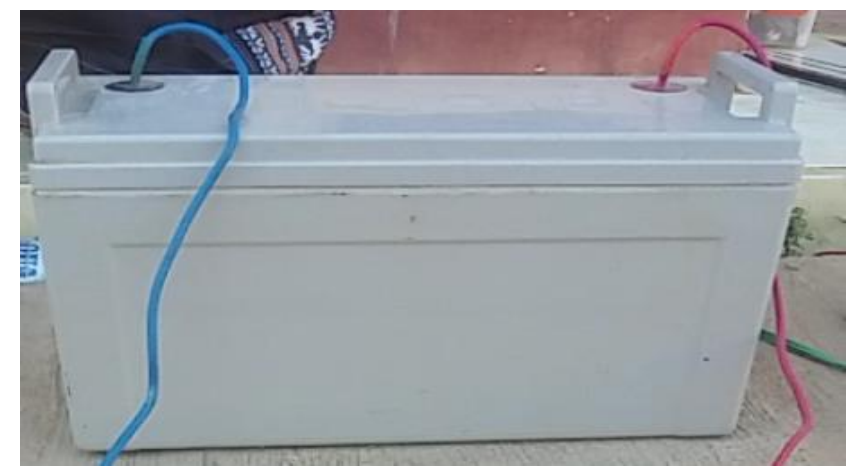

Gambar 4.9 Baterai VRLA deep cycle type WPS 6-CNF-100

\subsection{Pengujian Modul PV dan Pompa Air DC}

Pengujian terhadap modul PV dilakukan pada Pengoperasian Kondisi Nyata (Real Operation Condition/ROC) test pada saat radiasi matahari dimulai dari jam 09:00 sampai dengan 15:00 WITA dengan sudut kemiringan modul PV sebesar $10^{\circ}$. Pengukurannya dilakukan setiap 30 menit agar mendapatkan kurva karakteristik I-V. Pengukuran arus dan tegangan modul PV menggunakan volt meter digital dan ampere meter digital sedangkan untuk suhu dan radiasi matahari menggunakan thermometer gun laser dan solar power meter.

Sedangkan untuk pengujian karakteristik pompa air dapat dilakukan dengan waktu yang ditentukan sendiri, dikarenakan pengujiannya dengan simulasi berbagai ketinggian sehingga pada saat ketinggiannya memasuki ketinggian maksimal maka pengujiannya telah selesai. Untuk pengujian karakteristik pompa air, pengukuran kemampuan pompa air dilakukan dengan menaikan ketinggian pipa dengan tinggi 0,5 meter hingga mencapai ketinggian maksimal. Pengukurannya dimulai dari ketinggian 0,5 meter dan pengukuran waktu menggunakan stopwatch untuk mengetahui berapa lama 
waktu yang dibutuhkan untuk pengisian wadah penampungan air per liter, dan dilakukan pengukuran arus-tegangan pompa air menggunakan ampere meter digital dan volt meter digital untuk megetahui perubahan arustegangan pompa air DC 50 watt.

\subsection{Hasil Pengujian Karakteristik Modul Surya 200 Wp}

Hasil pengukuran nilai besaran listrik yang merupakan keluaran dari modul surya ditampilkan dalam bentuk kurva. Tabel 4.1 menampilkan hasil pengukuran modul PV $200 \mathrm{Wp}$. Pengukuran ini dilakukan pada tanggal 24 Agustus dan dimulai dari pukul 09.00 sampai dengan pukul 15.00 WITA. Untuk pengukuran modul PV diambil rata - rata hasil pengukurannya sebesar Voc $=41,94 \mathrm{~V}$, Isc $=4,47 \mathrm{~A}, \mathrm{SR}=788 \mathrm{~W} / \mathrm{m}^{2}$, Suhu bawah modul $=49^{\circ} \mathrm{C}$ dan Suhu atas modul $=43{ }^{\circ} \mathrm{C}$. Tabel 4.1 menunjukkan hasil pengukuran modul PV 200 Wp yang dilakukan selama 6 jam.

Tabel 4.1 Hasil Pengukuran Modul PV 200 WP

\begin{tabular}{|c|c|c|c|c|c|c|c|c|}
\hline Pukul & \multicolumn{8}{|c|}{ Solar PV Monocrystalline $200 \mathrm{WP}$} \\
\hline (WITA) & $\operatorname{Voc}(\mathrm{V})$ & $\operatorname{Isc}(\mathrm{A})$ & $\mathrm{SR}\left(\mathrm{W} / \mathrm{m}^{2}\right)$ & $\mathrm{Sb}\left({ }^{0} \mathrm{C}\right)$ & $\mathrm{Po}(\mathrm{W})$ & $\operatorname{Pi}(W)$ & $\eta(\%)$ & $\mathrm{Sa}\left({ }_{0} \mathrm{C}\right)$ \\
\hline 9:00 & 42,26 & 4,80 & 643 & 45,00 & 202,85 & 868 & $23 \%$ & 41,00 \\
\hline 9:30 & 38,50 & 1,10 & 159 & 37,00 & 42,35 & 215 & $20 \%$ & 32,00 \\
\hline $10: 00$ & 43,70 & 4,30 & 947 & 44,00 & 187,91 & 1.278 & $15 \%$ & 37,00 \\
\hline $10: 30$ & 41,20 & 5,80 & 1.095 & 52,00 & 238,96 & 1.478 & $16 \%$ & 46,00 \\
\hline $11: 00$ & 42,40 & 5,50 & 1.031 & 50,00 & 233,20 & 1.392 & $17 \%$ & 45,00 \\
\hline $11: 30$ & 42,70 & 5,50 & 1.002 & 55,00 & 234,85 & 1.353 & $17 \%$ & 47,00 \\
\hline $12: 00$ & 41,90 & 5,60 & 1.002 & 60,00 & 234,64 & 1.353 & $17 \%$ & 51,00 \\
\hline $12: 30$ & 41,70 & 4,90 & 955 & 59,00 & 204,33 & 1.289 & $16 \%$ & 51,00 \\
\hline $13: 00$ & 41,80 & 5,10 & 1.009 & 58,00 & 213,18 & 1.362 & $16 \%$ & 52,00 \\
\hline $13: 30$ & 42,10 & 4,70 & 703 & 49,00 & 197,87 & 949 & $21 \%$ & 45,00 \\
\hline $14: 00$ & 42,00 & 4,20 & 624 & 51,00 & 176,40 & 842 & $21 \%$ & 46,00 \\
\hline $14: 30$ & 42,70 & 3,50 & 534 & 47,00 & 149,45 & 721 & $21 \%$ & 35,00 \\
\hline 15:00 & 42,20 & 3,10 & 413 & 41,00 & 130,82 & 558 & $23 \%$ & 35,00 \\
\hline Rata-rata & 41,94 & 4,47 & 778 & 49,85 & 188,22 & 1.051 & $19 \%$ & 43,31 \\
\hline
\end{tabular}


Arus maksimum sebesar 5,8 Amper pada tegangan 41,2 Volt dan radiasi matahari (SR) sebesar $1.095 \mathrm{~W} / \mathrm{m}^{2}$, sedangkan arus minimum sebesar 3,10 Amper pada tegangan 42,2 Volt dan radiasi matahari sebesar $413 \mathrm{~W} / \mathrm{m}^{2}$ . Radiasi matahari sangat berpengaruh terhadap arus listrik. Semakin tinggi radiasi matahari maka arus listrik semakin besar, sementara tegangan listrik akan timbul jika ada radiasi matahari. Karakteristik I-V disajikan pada Gambar 4.10

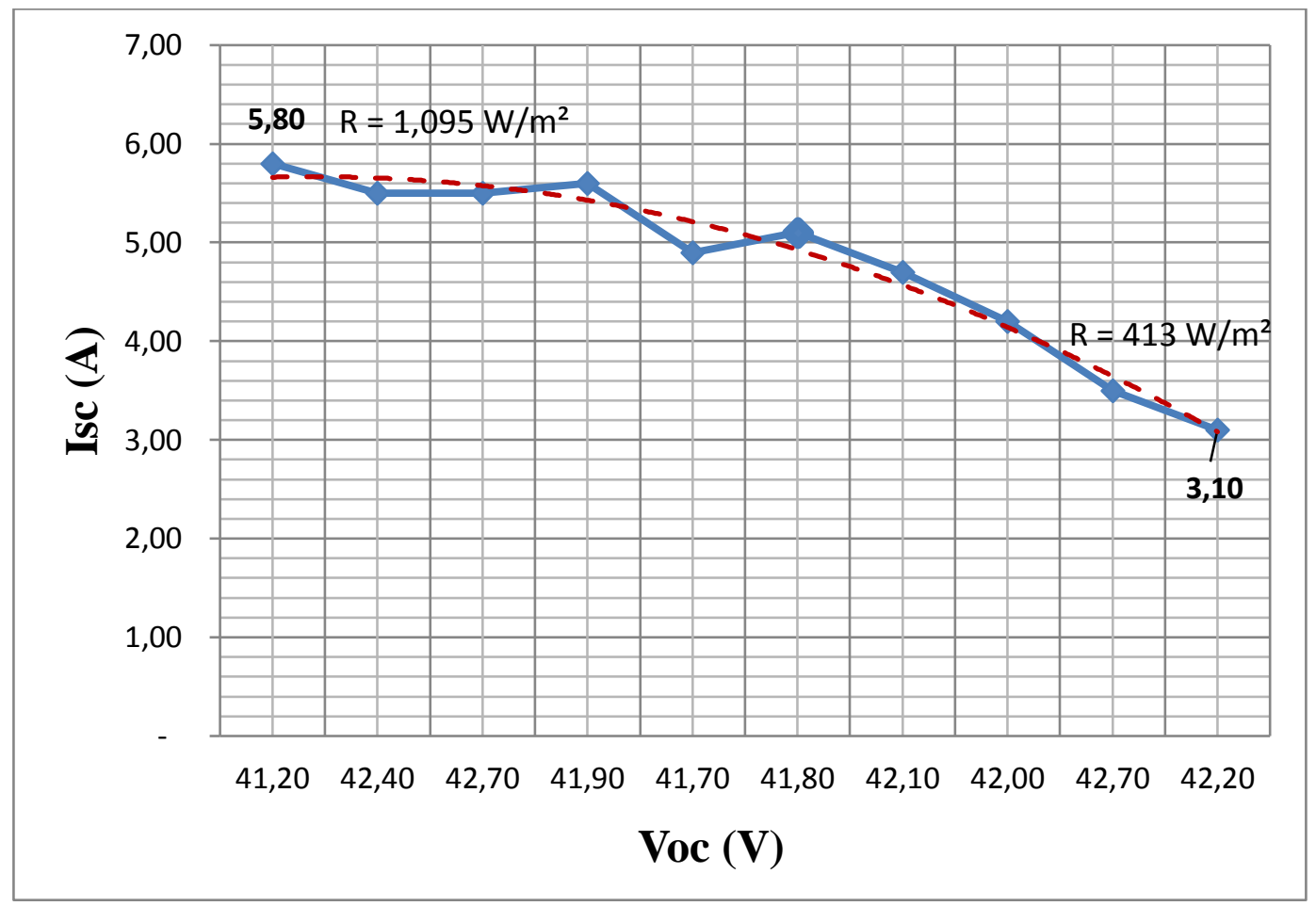

Gambar 4.10 Kurva Perubahan Arus dan Tegangan Modul PV 200 Wp

\subsection{Hasil Pengujian Pompa Air DC 50 Watt}

Hasil pengujian Pompa Air DC 50 Watt 12 Volt yang disuplai oleh baterai Deep cycle 100 Ah, 12 Volt yang telah terisi penuh melalui Modul PV $200 \mathrm{Wp}$ yang dikombinasikan dengan SCC menunjukkan bahwa kemampuan pompa air pada ketinggi (H) 0,5 meter menghasilkan debit air (Q) 600 L/jam, sementara kemampuan tertinggi pompa air ini adalah 3,5 meter dengan debit air maksimum $83 \mathrm{~L} / \mathrm{Jam}$. Kemampuan daya pompa air rata-rata adalah 50,19 Watt. Hasil Pengujian Pompa Air DC 50 Watt 12 Volt disajikan pada Tabel 4.2 . 
Tabel 4.2 Hasil Pengujian Pompa Air DC 50 Watt

\begin{tabular}{|c|r|r|r|r|r|}
\hline No. & $\mathrm{H}(\mathrm{m})$ & $\mathrm{Q}(\mathrm{L} / \mathrm{jam})$ & $\mathrm{Ip}(\mathrm{A})$ & $\mathrm{Vp}(\mathrm{V})$ & $\mathrm{Pp}(\mathrm{Watt})$ \\
\hline 1 & 0,5 & 600 & 5,70 & 9,00 & 51,30 \\
\hline 2 & 1,0 & 540 & 5,50 & 8,70 & 47,85 \\
\hline 3 & 1,5 & 360 & 4,60 & 7,90 & 36,34 \\
\hline 4 & 2,0 & 338 & 6,40 & 8,50 & 54,40 \\
\hline 5 & 2,5 & 300 & 4,50 & 8,30 & 37,35 \\
\hline 6 & 3,0 & 284 & 6,50 & 9,50 & 61,75 \\
\hline 7 & 3,5 & 83 & 6,70 & 9,30 & 62,31 \\
\hline \multicolumn{2}{|r|}{ Rata - rata } & 358 & 5,70 & 8,74 & 50,19 \\
\hline
\end{tabular}

Arus rata-rata pompa air (Ip) adalah 5,7 Amper. Dengan menggunakan baterai $100 \mathrm{Ah}$, maka dapat diperkirakan waktu pompa air mampu beroperasi 17,5 Jam saat modul PV tidak bekerja (Radiasi matahari nol).

Ketinggian tandon sangat mempengaruhi debit air. Semakin tinggi jarak sumur ke tandon maka debit air akan semakin kecil dengan trendline linier. Karakteristik debit air terhadap ketinggian tandon disajikan pada Gambar 4.11.

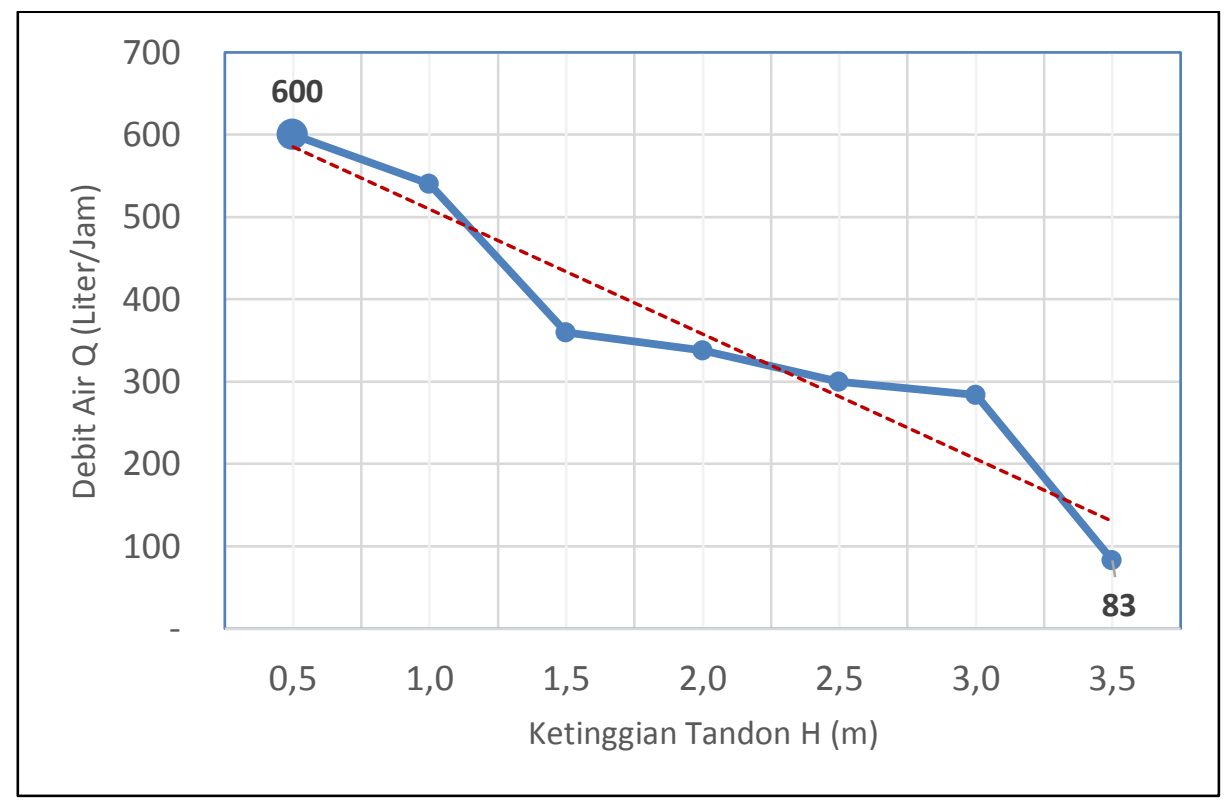

Gambar 4.11 Karakteristik debit air terhadap ketinggian tandon menggunakan Pompa Air DC 50 Watt 12 Volt 
Perubahan ketinggian air $(\mathrm{H})$ juga berpengaruh terhadap arus listrik yang timbul pada pompa air, semakin tinggi tandon maka arus listrik yang timbul pada pompa air (Ip) akan semakin besar dengan trendline linier. Pengaruh ketinggian tandon terhadap arus listrik pada pompa disajikan pada Gambar 4.12.

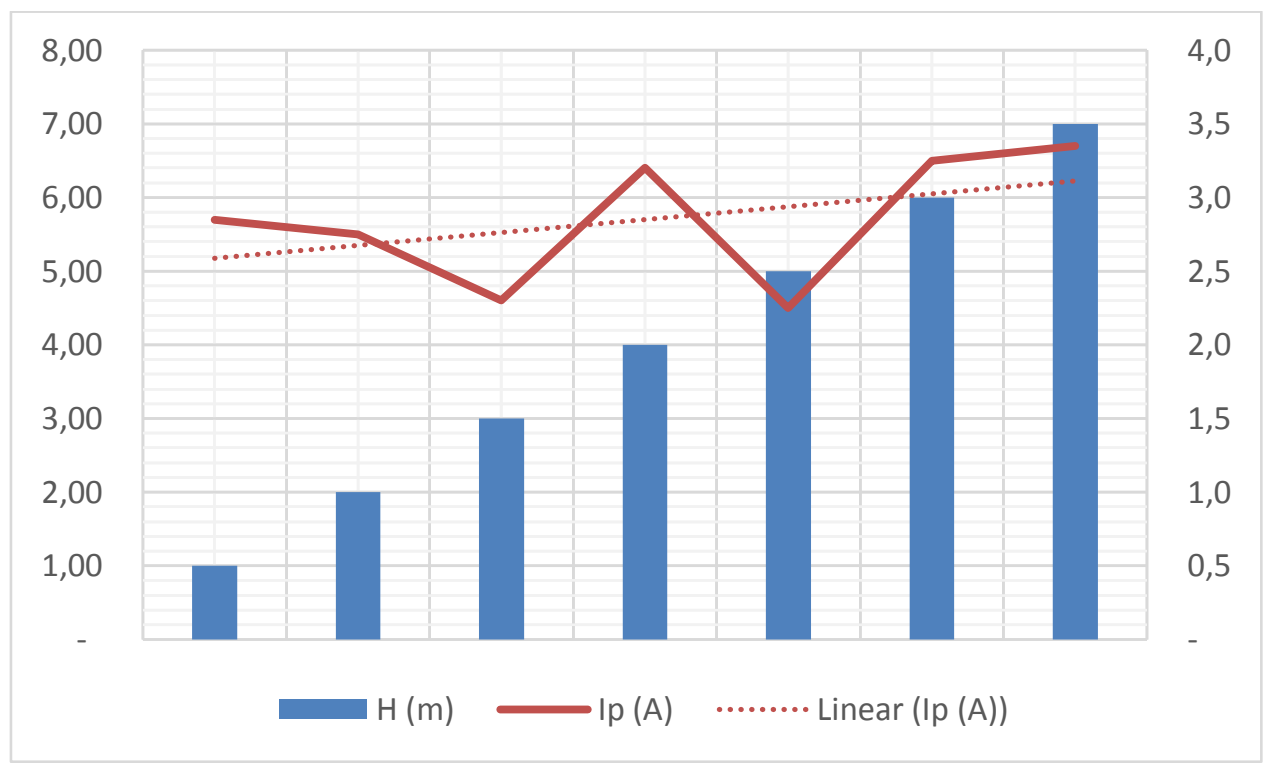

Gambar 4.12. Pengaruh ketinggian tandon terhadap arus listrik pada pompa 


\section{BAB V \\ PENUTUP}

\subsection{Kesimpulan}

Berdasarkan hasil penelitian Tugas Akhir ini maka dapat diambil kesimpulan sebagai berikut:

- Perubahan ketinggian tandon sangat mempengaruhi perubahan debit air dan arus. Semakin tinggi jarak sumur ke tandon maka debit air akan semakin kecil dan semakin tinggi jarak sumur ke tandon juga berpengaruh terhadap meningkatnya arus. Dari hasil pengujian didapatkan kemampuan pompa air DC 50 Watt 12 Volt pada ketinggi (H) 0,5 meter menghasilkan debit air (Q) 600 Liter/jam, sementara kemampuan tertinggi pompa air DC 50 Watt 12 Volt adalah 3,5 meter dengan debit air maksimum 83 Liter/Jam.

- Radiasi matahari sangat berpengaruh terhadap karakteristik modul PV. Semakin tinggi radiasi matahari maka output dari modul PV $200 \mathrm{Wp}$ akan semakin besar sebaliknya semakin kecil radiasi matahari maka output modul PV $200 \mathrm{Wp}$ semakin kecil. Untuk arus ketika radiasi matahari meningkat maka arus yang terukur juga meningkat, sementara tegangan listrik akan timbul jika ada radiasi matahari. Oleh karena pengaruh terhadap nilai arus dan tegangan maka daya yang dihasilkan oleh modul PV $200 \mathrm{Wp}$ juga ikut berpengaruh.

- Efisiensi modul Surya $200 \mathrm{Wp}$ pada Pengujian Kondisi Operasi Nyata (Real Operation Condition Test) adalah $19 \%$.

\subsection{Saran}

Disarankan kepada calon pengguna pompa air terutama pompa air DC 50 Watt 12 Volt yang terjual dipasaran dengan promosi dapat digunakan untuk ketinggian 5 meter, sebaiknya sebelum menggunakan di uji dahulu kemampuan pompa air tersebut agar sesuai dengan kebutuhan pompa air yang diperlukan. 


\section{DAFTAR PUSTAKA}

Napitupulu RAM, Simanjuntak S, Sibarani S. 2017. Pengaruh Material Monokristal dan Polikristal Terhadap Karakteristik Sel Surya $20 \mathrm{Wp}$ dengan tracking sistem Dua Sumbu. Laporan Penelitian. Universitas HKBP Nomensen. Medan.

Pribadi AB. 2016. Pembangkit Listrik Tenaga Surya dengan Rotasi Dinamis. Jurusan Teknik Elektro Fakultas Teknik Universitas Negeri Malang. Malang

Rahardjo I, Fitriana I. 2014. Analisis potensi pembangkit listrik tenaga surya di Indonesia. P3TKKE, BPPT. 11: 43-52.

Ramadhani B. 2018. Instalasi Pembangkit Listrik Tenaga Surya Dos \& Don'ts. Deutsche Gesellschaft für Internationale Zusammenarbeit (GIZ) $\mathrm{GmbH}$ Energising Development (EnDev). Indonesia. Jakarta

Satwiko S. 2012. Uji Karakteristik Sel Surya pada Sistem 24 Volt DC sebagai Catudaya pada Sistem Pembangkit Tenaga Hybrid. Prosiding Pertemuan Ilmiah XXVI HFI Jateng \& DIY, Purworejo 14 April 2012 ISSN: 0853-0823

Sinaga R. 2011. Pengaruh parameter lingkungan dan penempatan posisi modul terhadap luaran energi PLTS Menggunakan Solar Cell 50 Wp, 12 Volt. Studia Teknologia (SAINTEKS): IV (2):178-187

Sinaga R. Tambunan AH, Simangunsong CHB, Prastowo. 2017. Analisis alternatif solusi penyediaan sumber energi listrik: Studi kasus: Kabupaten Kupang. JTEP. 5(3):283-290

Sinaga R. Prastowo, Simangunsong B.C.H., Leabman A., Tambunan A.H. 2019. Analysis of barriers in supplying electricity using interpretative structural modeling. Energy Strategy Reviews. 25:11-17

Taufik M. 2016. Prototype pompa air portable tenaga surya. Jurnal UMJ. 19:1-3

Tukiman, Santoso P, Satmoko A. 2013. Perhitungan dan pemilihan pompa pada instalasi pengolahan air bebas mineral iradiator gamma kapasitas $200 \mathrm{KCI}$. Prosiding Pertemuan Iimiah Perekayasaan Perangkat Nuklir PRPNBATAN, 14 November 2013

[UURI 16] Undang Undang Republik Indonesia Nomor 16. 2016. Pengesahan Paris Agreement to the United Nation Faramework Convention on Climate Changes (Persetujuan Paris Atas Konvensi Kerangka Kerja Perserikatan Bangsa Bangsa Mengenai Perubahan Iklim. Jakarta (ID): Kementerian Hukum dan Hak Asasi Manusia Republik Indonesia. 

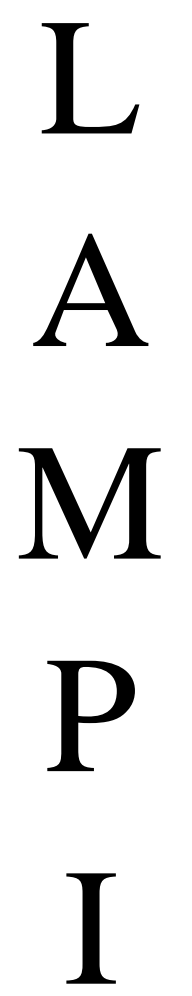

R

A

$\mathrm{N}$ 


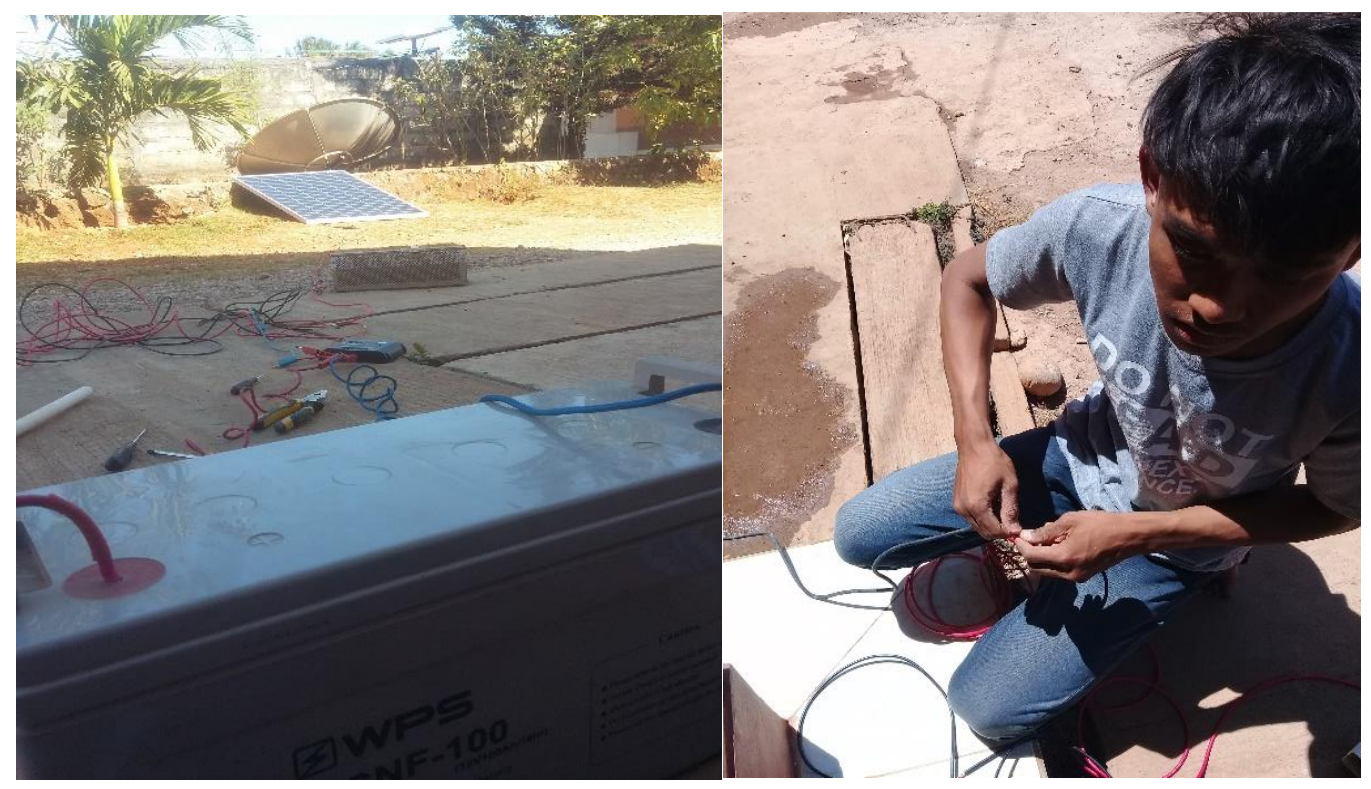

Lampiran 1. Rangkaian PABS Lampiran 2. Penyambungan Kabel

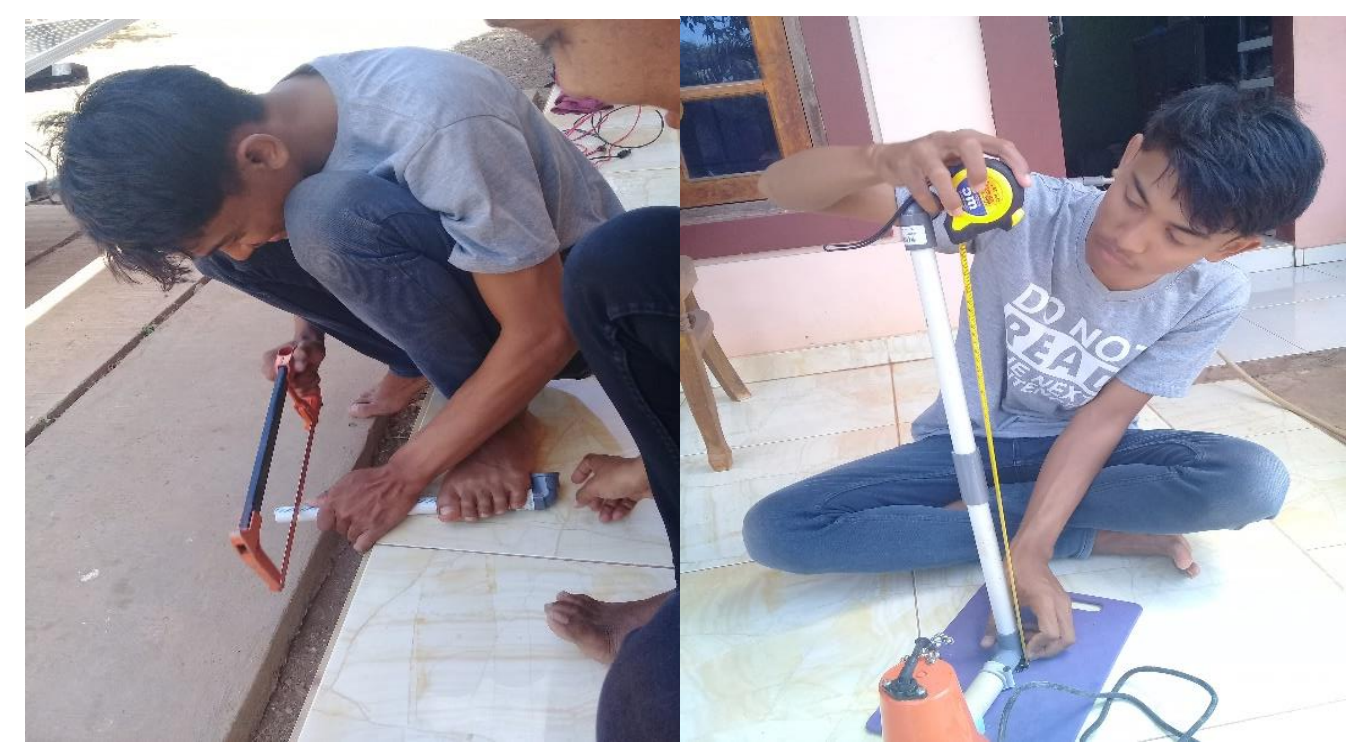

Lampiran 3. Pemotongan Pipa Simulasi Lampiran 4. Pengukuran Tinggi Pipa 


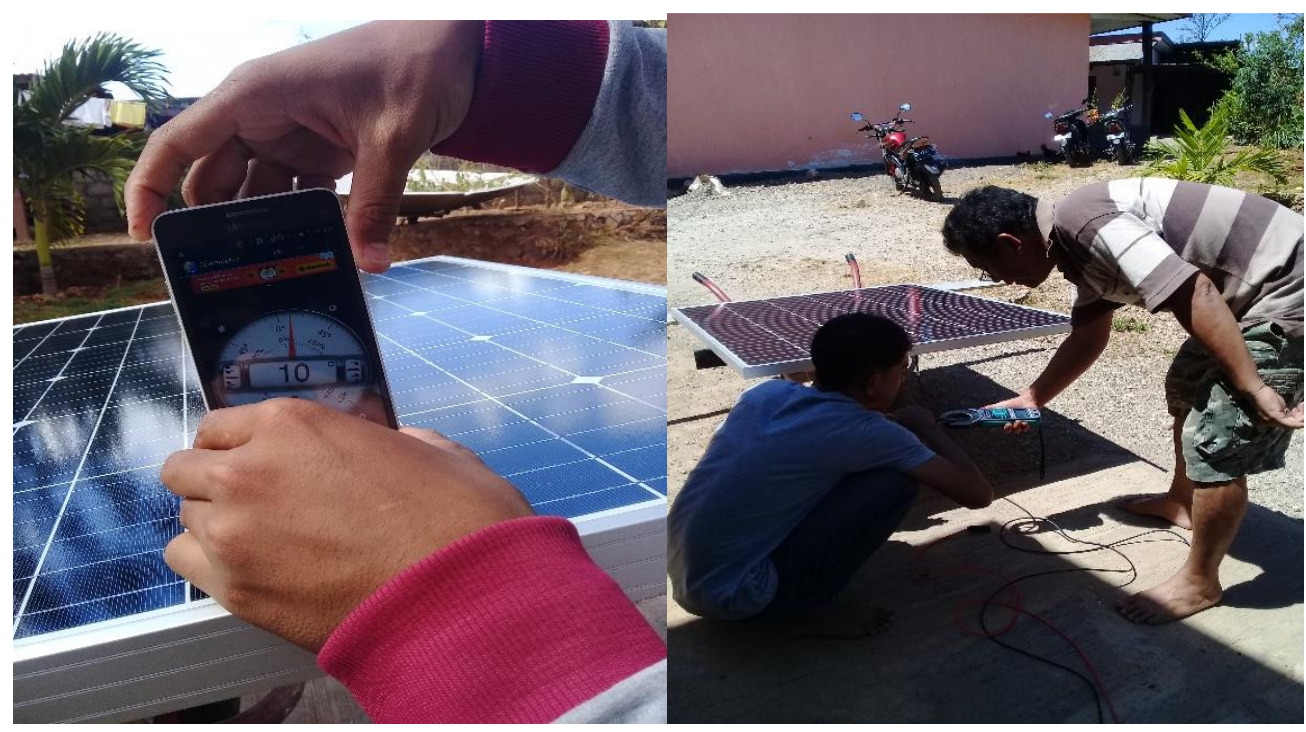

Lampiran 5. Pengukuran Kemiringan Modul. Lampiran 6. Pengarahan Teknik Pengukuran

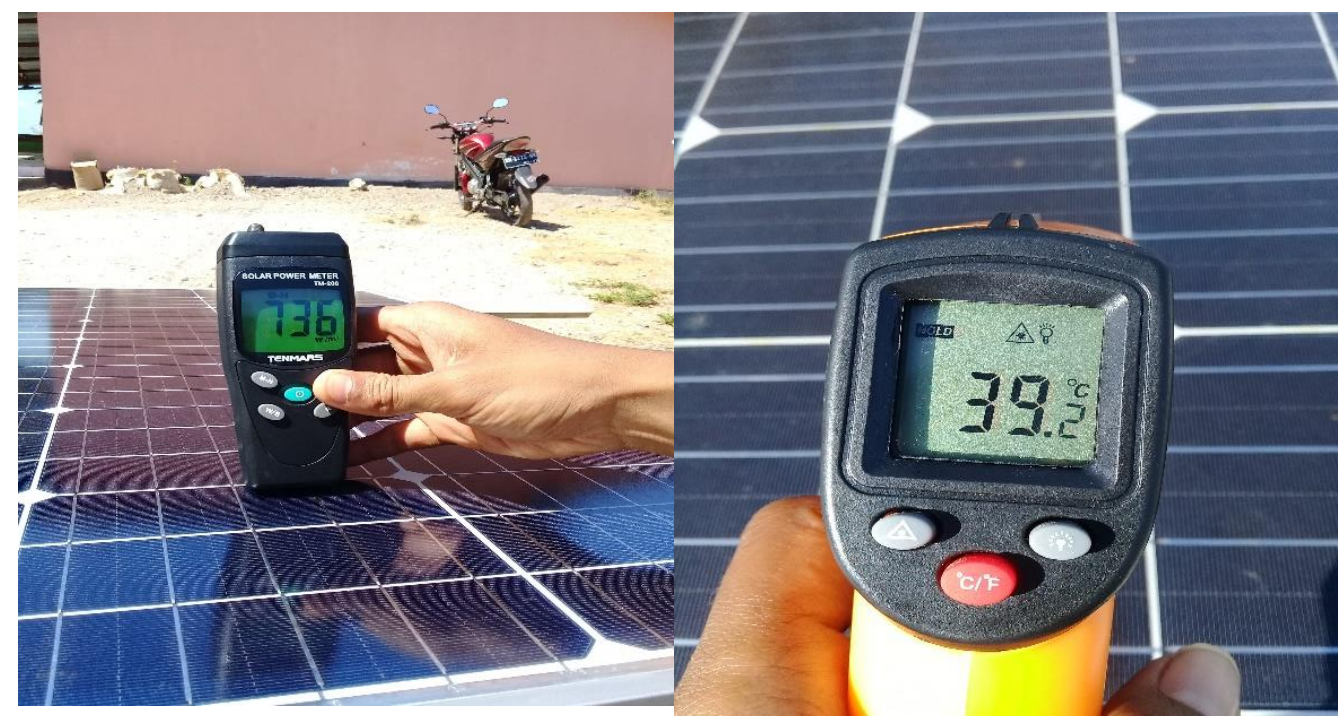

Lampiran 7. Pengukuran Radiasi Matahari Lampiran 8. Pengukuran Suhu Modul PV 


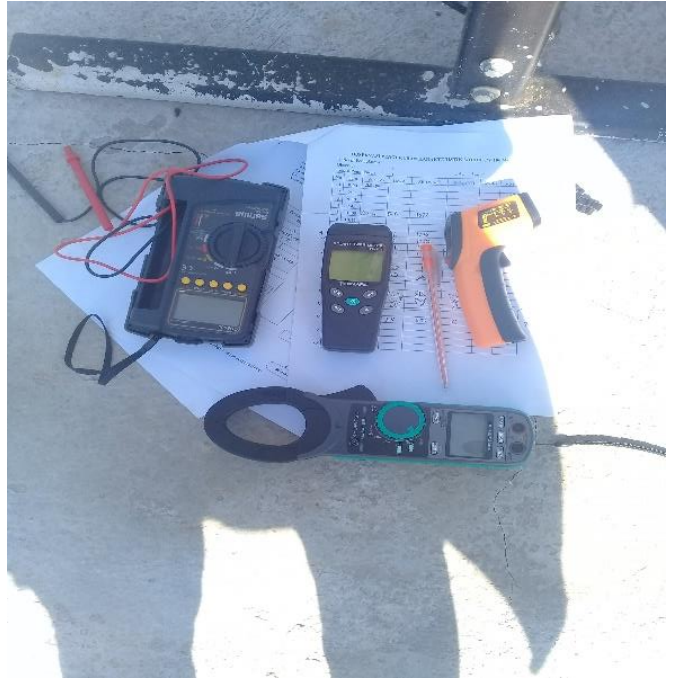

Lampiran 9. Instumen Alat Ukur

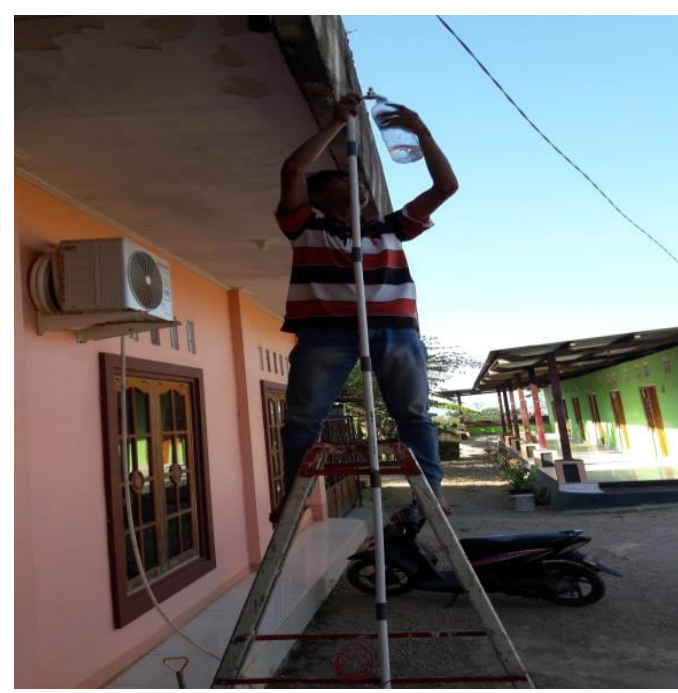

Lampiran 11. Pengujian Pompa Air

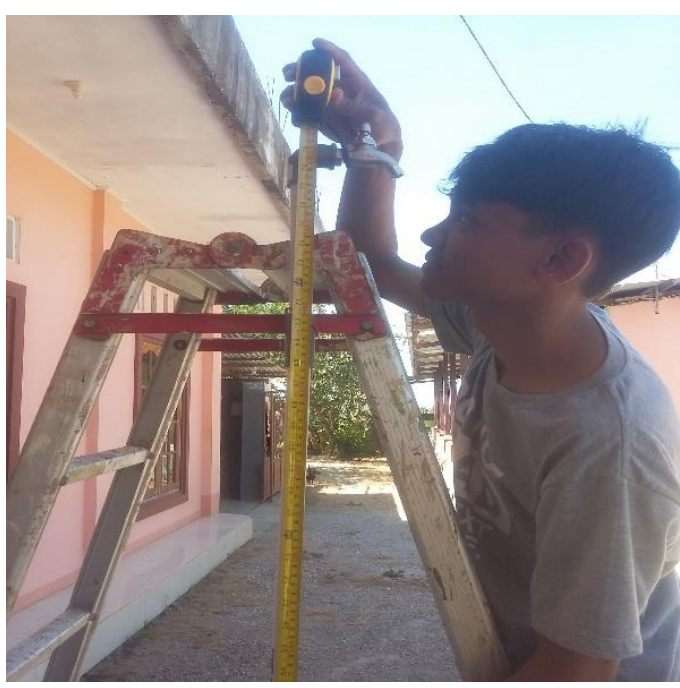

Lampiran 10. Pengukuran Ketinggian Tandon

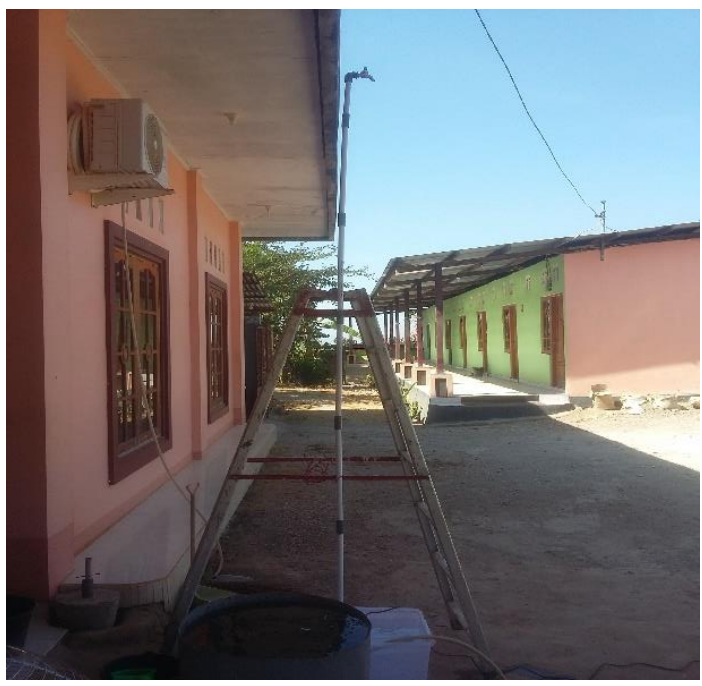

Lampiran 12. Simulasi Ketinggian Tandon 